Balkan Araştırma Enstitüsü Dergisi / Journal of Balkan Research Institute Cilt/Volume 9, Sayı/Number 1, Temmuz/July 2020, ss. 39-79.

Geliş - Received: 17.01.2020 Kabul - Accepted: 28.05.2020

DOI: 10.30903/Balkan.746403

ARASTIRMA MAKALESİ - RESEARCH ARTICLE

\title{
CUMHURIYET'İN İLK YILLARINDA İSTANBUL - BÜKREŞ HAVAYOLU HATTI KURULMA ÇABALARI VE IMTIYYAZI MESELESI
}

Feyza KURNAZ ŞAHIN*

ÖZ

Çalışmanın amacı Cumhuriyet döneminde İstanbul-Bükreş ticari havayolu nakliyatının başlatılmasına yönelik çabaları irdelemek olarak tanımlanır. Bu meyanda hattın kurulması için şirketlerin rekabeti ve bu rekabet içerisinde Fransız Compagnie Franco-Roumaine de Navigation Aérienne-CFRNA'nın imtiyaz elde etme çabaları, Türkiye Cumhuriyeti hükümetinin şirketin imtiyaz talebine karşı mesafeli duruşu ve bunun sebepleri ortaya konulmaya çalışılmıştır.

Osmanlı hükümeti İstanbul-Bükreş hattının imtiyazı için 11 Eylül 1920'de CFRNA ile bir mukavelename imzalamıştır. Ancak şirket 1923 yılından itibaren imtiyazlarını kaybetme tehlikesiyle karşı karşıya kalmıştır. Sonuçta CFRNA'nın isim değiştirmiş hali olan Compagnie Internationale de Navigation Aérienne-CIDNA ile Türkiye Cumhuriyeti hükümeti arasında 17 Ağustos 1925'de İstanbul-Bükreş hava yolculuğu ve posta nakline dair yeni sözleşme imzalanmıştır.

Anahtar Kelimeler: Franco-Romen, Bükreş, İstanbul, CIDNA, CFRNA

\section{ESTABLISHMENT EFFORTS FOR ISTANBUL - BUCHAREST AIRLINE AND THE CONCESSION ISSUE IN THE FIRST YEARS OF THE REPUBLIC}

\begin{abstract}
The purpose of the study was defined as to examine the efforts to start İstanbul - Bucharest commercial airline transportation in the Republic period. In this respect, it was tried to reveal the competition among the companies for the establishment of the line, French Compagnie Franco-Roumaine de Navigation
\end{abstract}

* Doç. Dr., Afyon Kocatepe Üniversitesi, Atatürk İlkeleri ve İnkılâp Tarihi Bölümü, Afyonkarahisar, ORCID: orcid.org/0000-0002-4858-1639, E-posta: fsahin@aku.edu.tr 


\section{FEYZA KURNAZ ŞAHIN}

Aérienne-CFRNA's efforts for obtaining a concession in this rivalry, and firm stance of the Turkish government against the concession demand of the company and the reasons of this.

The Ottoman government signed a contract for the concession of İstanbulBucharest line with the CFRNA on 11 September 1920. However, the company faced with the risk of losing the concessions from the year of 1923. As a result, new contract was signed between the Compagnie Internationale de Navigation Aérienne-CIDNA which was the changed name of the CFRNA and the Turkish government with reference to İstanbul-Bucharest air travel and transfer of posts on 17 August 1925.

Keywords: Franco-Romanian, Bucharest, İstanbul, CIDNA, CFRNA

\section{Giriş}

Havayolu nakliyatı XX. yüzyılın başlarında çeşitli modellerde ve tiplerde uçakların üretimine paralel olarak gelişmiştir. ${ }^{1}$ Uçak üretimi 19091910 yıllarında daha ziyade askeri amaçlar için yapılmıştır. ${ }^{2}$ Ancak daha sonraki yıllarda posta ve yolcu taşıma gibi ticari amaçlar için de kullanılmıştır. ${ }^{3}$ Osmanlı Devleti askeri havacılık çalışmalarını 1909'da Harbiye Nazırı Mahmut Şevket Paşa zamanında başlatmıştır. ${ }^{4} \mathrm{Bu}$ yıldan itibaren yapılan çalışmalar neticesinde 1912 yılında Yeşilköy Havalimanı askeri amaçlar için faaliyete geçmiştir. ${ }^{5}$ Osmanlı Devleti’nde askeri havacılık alanında yaşanan gelişmelerde Miralay Süreyya (İlmen) Bey’in önemli katkılarının olduğunu ifade etmek gereklidir. ${ }^{6} \mathrm{Bu}$ cümleden olarak Süreyya Bey'in askeri havacılık faaliyetlerini yürütmek için görevlendirilmesinin

${ }^{1}$ Yavuz Kansu ve Sermet Şensöz ve Yılmaz Öztuna, En Eski Çağlardan I. Dünya Savaşına Kadar Havacılık Tarihinde Türkler I, Ankara 1971, s. 89-94; Ahmet Çelik, II. Meşrutiyet Döneminde Türk Hava Kuvvetleri, Selçuk Üniversitesi Sosyal Bilimler Enstitüsü, Yayımlanmamış Yüksek Lisans Tezi, Danışman: Yrd. Doç. Dr. İzzet Sak, Konya 2004, s. 6.

${ }^{2}$ Havacllık Tarihi, Türk Tayyare Cemiyeti Yay., Ankara 1930, s. 254-255; Mazhar Nedim Göknil, Hava Hukuku, İstanbul Üniversitesi Hukuk Fakültesi Yay, İstanbul 1951, s. 16-17.

${ }^{3}$ Fevzi Sürmeli, Hikmet Seçim, Halim Sözbilir, Sivil Havacılık Yönetimi, Anadolu Üniversitesi Yay., Eskişehir 1991, s. 2-3.

${ }^{4}$ Kürşad Karacagil, "Balkan Savaşlarında Osmanlı Devletinde Havacılık Faaliyetleri”, Türk Dünyası Araştırmaları, Sayı 200, Ekim 2012, s. 74.

${ }^{5}$ Türk Istiklal Harbi Vnci Cilt, Deniz Cephesi ve Hava Harekatı, Genelkurmay Başkanlığı Yay, Ankara 1964, s. 121; Dünden Bugüne Türk Hava Yollarl 1933-1983, (haz.) İlyas Albayrak, Cem Ofset, İstanbul 1985, s. 12.

${ }^{6}$ Karacagil, "Balkan Savaşlarında...", s. 75; Kürşad Karacagil, Süreyya İlmen ’in Hayatı, Faaliyetleri ve Eserleri, Marmara Üniversitesi Türkiyat Araştırmaları Enstitüsü, Yayımlanmamış Doktora Tezi, Danışman: Prof. Dr. Süleyman Beyoğlu, İstanbul 2011, s. 1339. 


\section{CUMHURIYYET'IN İLK YILLARINDA İSTANBUL-BÜKRES HAVAYOLU HATTI KURULMA ÇABALARI VE İMTIYAZI MESELESI}

ardından bu alanda bir bilgi birikimi olușturulmuş ve havacılık alanında teşkilatlanma başlamıştır. ${ }^{7}$

Osmanlı Devleti'nde ilk hava posta taşımacılığı ise 1914 yılında bașlamıștır. $^{8}$ İstanbul-Bükreș arasındaki ilk havayolu ulaşımı, hava posta taşımacıllığ1 vesilesiyle olmuştur. Fransızlar 1919-1922 yılları arasında “Armèes Allieès En Orient-Poste Aèrienne" (Doğu Müttefik Kuvvetleri Hava Postası) yoluyla bu hatta posta işletmeciliği yapmışlardır. ${ }^{9}$ Osmanlı hükümeti Fransa ile sadece posta nakline ilişkin olmak üzere bir mukavelename de imzalamıştır. 8 Ekim 1919 tarihli bir belgeden anlaşıldığına göre, Dersaadet ile Bükreş arasında haftada iki defa sefer yapan Fransız uçakları ile Osmanlı postalarının da nakledilmesi amacıyla bir itilafname imzalanmış ve anlaşma Meclis-i Vükelânın 8 Ekim 1919 tarihli toplantısında müzakere edilerek onaylanmıştır. ${ }^{10}$

I. Dünya Savaşı'nın ardından Avrupalı devletler havayolu nakliyatı alanında rekabete başlamışlar ve bu alanda çeșitli imtiyazlar elde etme çabası içerisine girmişlerdir. Bu amaçla devlet destekli şirketler kurarak havayolu nakliyatı ile yolcu, posta, koli ve diğer malzemeleri taşımak için çeşitli devletlerle sözleşmeler imzalamışlardır. Bu hususta İngiltere, Almanya, Fransa ve İtalya başı çeken ülkeler olmuştur. ${ }^{11} 1920$ 'lerde ticari havacılık yükselmiş, tüm büyük devletler için havayolları politik boyutlarıyla birlikte önemli bir etki alanı haline gelmiştir. ${ }^{12}$ I. Dünya Savaşı sonrasında ivme

\footnotetext{
${ }^{7}$ Kürşad Karacagil, “Osmanlı Havacılık Teşkilatının Kuruluşuna Dair Nizamnameler”, Türk Kültürü İncelemeleri Dergisi, Say1 27, Güz 2012, s. 47.

${ }^{8}$ Ahmet Demir, Havacılık ve Uzay Endüstrisinin Yapısı, Işsleyişi ve Türkiye'de Gelişme Olanakları Üzerinde Bir Araştırma, Ankara Üniversitesi Siyasal Bilgiler Fakültesi Yay., Ankara 1977, s. 37-38; Selçuk Kileci, "Hava Taşımacılığımızın Dünyadaki Yeri ve Kapasitenin Artırılması Hakkında Öneriler", IV. Uluslararası Havacılık Sempozyumu 5-6 Nisan 1993 Eskişehir, Anadolu Üniversitesi Yay., Eskişehir 1994, s. 9.

${ }^{9}$ Ergün Kaya, Havaalanlarında Fiyatlandırma Açısından Muhasebe Bilgi Sistemi, Anadolu Üniversitesi Yay., Eskişehir 2000, s. 24-25.

${ }^{10}$ Cumhurbaşkanlığı Devlet Arşivleri Başkanlığı Osmanlı Arşivi (BOA), Meclis-i Vükelâ Mazbatalart (MV.), 217/18, (H.13 Muharrem 1338/8 Teşrinievvel 1335/8 Ekim 1919).

${ }^{11}$ Cumhurbaşkanlığı Devlet Arşivleri Başkanlığı Cumhuriyet Arşivi (BCA), 230.0.0.0/56.1.1, 24-27, (27 Ocak 1922); Ercan Haytoğlu, "Cumhuriyetin İlk Yıllarında Ticari Havayolu Taşımacılığında İmtiyazlı İlk Şirket: Aero Espresso Italiana (1924-1935)”, Hacettepe Üniversitesi Cumhuriyet Tarihi Araştırmaları Dergisi (CTAD), Y11 14, Sayı 28, Güz 2018, s. 82-83; Necat Tüzün, Hava ve Kara Taşıma Hukuku, Ankara İktisadi ve Ticari İlimler Akademisi Yay., Ankara 1981, s. 104.

12 Jérôme de Lespinois, "Qu'est-ce que la Diplomatie Aérienne?", ASPJ Afrique \& Francophonie - 4e Trimestre 2012, s. 68.
} 


\section{FEYZA KURNAZ ŞAHIN}

kazanan havayolu taşımacılığı siyasi açıdan da önemli olmuştur. Devletler havayolu hattı oluşturdukları bölgelerle ve devletlerle diplomatik ilişkilerini daha çabuk şekillendirmişlerdir. Nitekim Fransa, Orta ve Doğu Avrupa'daki şehirlerle bağlantılı hatlar kurarak ittifak sistemini güçlendirmiş ve adeta "hava diplomasisi" gerçekleştirmiştir. ${ }^{13}$

Osmanlı Devleti de bu alandaki gelişmelere kayıtsız kalmamış çeşitli şirketlerle imtiyaz anlaşmaları imzalamıştır. İstanbul-Bükreş havayolu hattı ve postaların nakledilmesi buna güzel bir örnek teşkil etmiştir. Osmanlı'yı Avrupa'ya bağlayan ilk ticari hava nakliyatı 1922'de Franco-Romen Havấ Seyrüsefer Kumpanyası tarafindan oluşturulan Bükreş-İstanbul hattı olmuştur. Anılan hatla ilgili ilk mukavelename 26 Ağustos 1920'de imzalanmış ve 11 Eylül 1920 'de onaylanmıştır. ${ }^{14}$ Ancak şirket uçuşlarını ancak 1922'de gerçekleştirebilmiştir. Mukavelename gereğince orijinal adı Compagnie Franco-Roumaine de Navigation Aérienne (CFRNA) olan şirket Paris-Prag-Viyana-Budapeşte-Bükreş-İstanbul hatları arasında ticari hava nakliyatı için faaliyet göstermiştir. ${ }^{15}$

Osmanlı hükümetinin İstanbul-Bükreş havayolu taşımacıllı̆ı için mukavele imzaladığı CFRNA, Fransız-Rumen ortaklığı ile kurulmuş olup yönetim merkezi Paris'tedir. ${ }^{16}$ Şirket uluslararası hava nakliyatı alanında önde gelen kuruluşlardandır. CFRNA'nın idare meclisi başkanı Fransız Harbiye Nezaretinde daha önce havacılık şubesi müdürlügü yapmış olan Cezal Duval, genel müdürü Mösyö Pierre Claret de Fleurieu'dir. Şirketin fenni müdürlüğünü ise Mösyö Revi Villomi üstlenmiştir. CFRNA, 1921 yıl1 içerisinde Paris-Strazburg-Prag-Varşova hattında her gün sefer düzenlemiş, 1922 yılında ise faaliyetlerini genişleterek Haziran ayından itibaren ParisStrazburg-Prag- Viyana-Budapeşte-Bükreş ve İstanbul-Yeşilköy hattında seferlerini başlatmıştır. ${ }^{17}$ Şirket, Çekoslovakya, Polonya, Macaristan,

\footnotetext{
${ }^{13}$ Lespinois, a.g.m., s. 68.

${ }^{14}$ BOA, Dâhiliye Nezareti İdare-i Umumiye Kalemi (DH.I.UM.), 16-5/1-46, 2-4, (26 Ağustos 1920); BOA, DH.I.UM., 16-5/1-46, 3-1, (11 Teşrinievvel 1338/11 Ekim 1922).

${ }^{15}$ BCA, 230.0.0.0/56.1.1, 24-27, (27 Ocak 1922); Haytoğlu, a.g.m., s. 82-83; Tüzün, a.g.e., s. 104.

${ }^{16}$ Pyramides sokak 22 numaradadır. BOA, MV., 252/94, (H.24.12.1338/8 Eylül 1920).

171920 y1lında on milyon frank sermaye ile tesis edilen şirket, sermayesini kısa zamanda arttırarak yirmi milyon franka ulaştırmıştır. Bkz. BCA, 230.0.0.0/56.1.1, 24-27, (27 Ocak 1922); Sacha Markovic, "Le Rôle de l'Etat Dans la Naissance de L'aviation Commerciale Française (1918-1933)", Revue Belge de Philologie et D'histoire, Histoire Medievale, Moderne et Contemporaine, Cilt 78, fask. 3-4, 2000, s. 968.
} 


\section{CUMHURIYYET'IN İLK YILLARINDA İSTANBUL-BÜKRES HAVAYOLU HATTI KURULMA ÇABALARI VE İMTIYAZI MESELESI}

Avusturya, Yugoslavya ve Romanya gibi birçok devletle hava taşımacıllı̆̆ hususunda beş, on veya yirmi yıl süreli mukaveleler imzalamıştır. ${ }^{18}$

Fransa için havayolu bağlantıları ekonomik ve stratejik öneminin yanında askeri açıdan da oldukça değerlidir. Fransa, Orta ve Doğu Avrupa ile Balkanlar'da bulunan küçük ülkelerle havayolu bağlantıları oluşturarak bu bölgelerdeki aktif varlığını kuvvetlendirme amacını gütmüş, bu vesile ile anılan ülkelerle arasındaki iletişimi arttırmıştır. Fransa'nın özellikle 1920 'lerden sonra havayolu nakliyatına eğilmesinin en önemli nedenlerinden birisi de Almanya'nın sivil havacılık alanındaki hırs ve tehdidini ortadan kaldırmak olmuştur. Ayrıca Bolşevik devriminin genişlemesi, Avrupa'da politik, sosyal ve ekonomik etkilerinin yayılması Fransa'yı harekete geçirmiştir. Bu meyanda Fransa, Orta ve Doğu Avrupa ülkeleriyle havayolu hatları oluşturup bölgedeki nüfuzunu güçlendirerek Bolşevik etkisini en aza indirmeye çalışmıştır. $\mathrm{Bu}$ hamlenin yapılmasında Fransa askeri misyonunun da etkisi büyüktür. Çünkü $C F R N A$, Fransa askeri kuvvetleri içinde olan "Air Navigation”a bağlı olarak çalışmıştır. Şirketin yönetim yapısına bakıldığında tamamen askerlerden oluştuğu görülmektedir. Mesela şirketin yönetim kurulu başkanı Duval eski askeri havacılık şubesi başkanıdır. Keza genel müdür Fleurieu ise I. Dünya Savaşı'na katılmış bir askeri pilottur. ${ }^{19}$

Fransız şirket hava hatlarını genişletmek amacıyla Osmanlı hükümeti ile de hava nakliyatı hususunda görüşmelere başlamıştır. ${ }^{20}$ Posta ve Telgraf ve Telefon Müdüriyeti Umumiyesi ile Franco-Romen Havaî Seyrüsefer Şirketi (CFRNA) arasında imzalanmak üzere düzenlenen sözleşme taraflar

\footnotetext{
${ }^{18}$ BCA, 230.0.0.0/57.8.1, 140-147 (tarihsiz).

${ }^{19}$ Markovic, a.g.m., s. 975.

${ }^{20}$ BOA, Babiali Evrak Odasi Divan Kalemi Mukavelenameler (A.DVN.MKL.), 69/30, 1, 1, 2 (H. 02.01.1340/5 Eylül 1921); BCA, 230.0.0.0/56.1.1, 24-27 (27 Ocak 1922).
} 


\section{FEYZA KURNAZ ŞAHIN}

arasında yapılan görüşmeler neticesinde son şeklini almışs ${ }^{21}$ ve nihayet 11 Eylül 1920'de Osmanlı hükümeti sözleşmeyi onaylamıştır. ${ }^{22}$

11 Eylül 1920'de imzalanan ve on maddeden oluşan mukavelenamenin giriş kısmında sözleşmenin Osmanlı hükümeti adına Dahiliye Nazırı Reşid Mümtaz Paşa ile Paris'te bulunan CFRNA temsilcisi meclis-i idare azası ve genel müdürü Comte Pierre de Fleurieu arasında imzalandığı ifade edilmiştir. Sözleşmenin ilk maddesine göre şirket, mukavele imzalandığı tarihten itibaren bir yılda her iki yönde ortalama iki yüz gün sefer yapacaktır. Bir yıl zarfinda düzenli olarak havayolu seferleri yapılamadığı takdirde mukavele geçersiz sayılacaktır. Şirket Bükreş, Belgrad, Peşte (Budapeşte), Viyana, Prag ve Strazburg'dan geçmek üzere Paris ile İstanbul arasında düzenli olarak uçak işletmeyi taahhüt etmiştir. Sözleşmenin ikinci maddesine göre Osmanlı hükümeti, CFRNA'nın belli zamanlarda Osmanlı toprakları dâhilinde uçak ile yolcu, eşya, emtia ve posta nakliyatı yapmasına müsaade edecektir. ${ }^{23}$

Üçüncü madde uçakların karaya inmesi ile ilgilidir. Buna göre Osmanlı hükümeti, şirket uçaklarının Osmanlı toprakları içinde karaya inmesine müsaade etmiştir. ${ }^{24}$ Dördüncü maddeye göre hükümet, şirketin umumi faydalar sağlayan bir hizmete girişmesinden dolayı, imkânlar ölçüsünde şirkete yardım etmeyi ve gereken kolaylığı sağlamayı taahhüt etmiştir. Beşinci madde uluslararası mektup nakliyatı hususunda Posta, Telgraf ve Telefon Müdüriyeti Umumiyesi ile ayrica bir mukavele imzalanacağını bildirmektedir. Altıncı maddede Osmanlı hükümeti, şirkete ait veya şirket tarafindan satın alınmış bulunan fenni malzeme ile benzinin gümrük vergisi olmaksızın Osmanlı topraklarına ithal ve ihracı hususunda

\footnotetext{
${ }^{21} 9$ Eylül 1920 (24 Zilhicce 1338/9 Eylül 1336) tarihli bir Meclis-i Vükela mazbatasında Posta ve Telgraf ve Telefon Müdüriyeti Umumiyesi ile Franco-Romen Havaî Seyrüsefer Şirketi (CFRNA) arasında imzalanmak üzere düzenlenen ve Dahiliye Nezaretine gönderilen mukavelename layihası ufak değişiklikler yapılarak padişah iradesi ve Meclis-i Vükela kararıyla kabul edilmiş ve şirkete ruhsat verilmiştir. Osmanlı hükümeti ile CFRNA arasında imzalanan mukavelename Meclis-i Vükelada da uygun görülmüştür. Mukavelename sureti 11 Eylül 1920'de ekleriyle birlikte Sadaret evrakına gönderilmiştir. Ayrıntılı bilgi için bkz. BOA, MV., 252/94, (H.24.12.1338/8 Eylül 1920); BOA, Irade Dosya Usulü (İ.DUIT.), 22/28, 1-1, (H.24.12.1338/8 Eylül 1920); BOA, I.DUiT., 22/28, 1-2, (H.24.12.1338/8 Eylül 1920); BOA, I.DUIT., 22/28, 2-1, (H.24.12.1338/8 Eylül 1920); BOA, DH.I.UM., 16-5/1-46, 3-1, (11 Teşrinievvel 1338/11 Ekim 1922).

${ }^{22}$ BOA, DH.I.UM. 16-5/1-46, 3-1, (11 Teşrinievvel 1338/11 Ekim 1922).

23 BOA, DH.I.UM., 16-5/1-46, 2-4, (26 Ağustos 1920); DH.I.UM., 16-5/1-46, 3-1, (11 Teşrinievvel 1338/11 Ekim 1922).

${ }^{24}$ BOA, I.DUIT., 22/28, 3-1, (H.24.12.1338/8 Eylül 1920).
} 


\section{CUMHURIYYET'IN İLK YILLARINDA İSTANBUL-BÜKRES HAVAYOLU HATTI KURULMA ÇABALARI VE İMTIYAZI MESELESI}

şirkete izin vereceğini taahhüt etmiştir. Bu malzemeler sadece şirketin işletme ihtiyacını karşılamak amacına yöneliktir. Mukavelename yürürlüğe girdiği tarihten itibaren beş yıl süreyle geçerli olacaktır ve istenirse beşer yıl müddetlerle uzatılabilecektir. Taraflar sözleşmeye son vermek isterlerse iki ay önceden birbirlerini haberdar edeceklerdir. Keza sözleşmenin Fransızca metninin esas alındığı ve bir nüshasının İstanbul'da düzenlendiği bildirilmiştir. ${ }^{25}$ Şirket mukavelename imzalandığı andan itibaren bir yıl içinde uçuşlara başlamak zorundadır. ${ }^{26}$

CFRNA, 11 Eylül 1920 tarihinde imzalanan bu anlaşma ile Paris'ten İstanbul'a havayolu hattını oluşturmuştur. Mukavelenin imzalanması Fransa'da tam bir başarı olarak nitelendirilmiştii ${ }^{27}$ Şirket, İstanbul-Bükreş hava nakliyatına ancak 1922 yılında başlayabilmiştir. ${ }^{28}$ CFRNA'nın daha sonraki yıllarda isim değişikliğine gittiği anlaşılmaktadır. Şirket, Fransız ve Rumen ortaklığında kurulmasına rağmen ana sermayedar Rumen Marmeresh Bank, hisselerini Fransız ortağına devretmiştir. Böylece işletme tamamen Fransızların hâkimiyetine geçmiştir. ${ }^{29} 1$ Ocak 1925 tarihinden itibaren şirketin orijinal ismi Compagnie Internationale de Navigation Aérienne (CIDNA) yani Beynelmilel Havaî Seyrüsefer Şirketi olmuştur. ${ }^{30}$

Çalışmanın temel amacı Cumhuriyet döneminde İstanbul-Bükreş ticari havayolu nakliyatının başlatılmasına yönelik çabaları irdelemektir. $\mathrm{Bu}$ meyanda hattın kurulması için Fransız, Alman ve İtalyan şirketlerinin rekabeti ve bu rekabet içerisinde Fransız Franco-Romen Havaî Seyrüsefer Şirketi (Compagnie Franco-Roumaine de Navigation Aérienne-CFRNA)'nin imtiyaz elde etme çabaları, Türkiye Cumhuriyeti hükümetinin şirketin imtiyaz talebine karşı mesafeli duruşu ve bunun sebepleri ortaya konulmaya çalışılmıştır. Keza İstanbul-Bükreş havayolu hattı müsaadesinin Türkiye Cumhuriyeti hükümeti tarafından Franco-Romen Şirketi'nin isim değiştirmiş hali olan Beynelmilel Havaî Seyrüsefer Şirketi (Compagnie Internationale de

\footnotetext{
${ }^{25}$ BOA, I.DUIT., 22/28, 3-2, (H.24.12.1338/8 Eylül 1920); BOA, DH.İ.UM., 16-5/1-46, 1-1, (5 Eylül 1336/5 Eylül 1920).

${ }^{26}$ BOA, DH.I. UM., 16-5/1-46, 3-1, (11 Teşrinievvel 1338/11 Ekim 1922).

${ }^{27}$ BOA, DH.I. UM. , 16-5/1-46, 3-1, (11 Teşrinievvel 1338/11 Ekim 1922).

${ }^{28}$ BCA, 230.0.0.0/57.8.1, 185, (15 Teşrinisani 1339/15 Kasım 1923).

29 Ender Gerede ve Gamze Orhan, "Türk Havayolu Taşımacılığındaki Ekonomik Düzenlemelerin Gelişim Süreci”, Havayolu Taşımacıllğı ve Ekonomik Düzenlemeler Teori ve Türkiye Uygulaması, Sivil Havacılık Genel Müdürlüğü Yay., Ankara 2015, s. 178; Haytoğlu, a.g.m., s. 83.

${ }^{30}$ BCA, 230.0.0.0/57.6.1.
} 


\section{FEYZA KURNAZ ŞAHIN}

Navigation Aérienne-CIDNA)'ne verilme süreci ve şirketle imzalanan mukavele şartları da çalışmada ele alınan diğer bir husus olmuştur.

\section{Compagnie Franco-Roumaine de Navigation Aérienne Şirketi (CFRNA)'nin TBMM Hükümeti ile Görüşme Çabaları}

Girişte de ifade edildiği gibi Osmanlı hükümeti ile CFRNA arasında 11 Eylül 1920'de Bükreş-İstanbul havayolu nakliyatı ile ilgili bir mukavelename yapılmış ve mukavelenin ardından Bükreş-İstanbul hattı esasen 1922 'de birkaç ay işlemiştir. ${ }^{31} \mathrm{Bu}$ tarihten sonra şirketin havayolu nakliyatı düzenli olmamıştır.

Esasen CFRNA ile Osmanlı Devleti arasında yapılan sözleşmeden sonra Anadolu'da birçok şey değişmiştir. Yunanlıların Anadolu macerası ve Milli Mücadele 11 Ekim 1922'de Mudanya Mütarekesi'nin imzalanmasıyla sona ermiş ve barış süreci başlamıştı. Milli Mücadele döneminde Mustafa Kemal Paşa için temel ilke tam bağımsızlıktı. Bu nedenle kapitülasyonların kaldırılması ve tam bağımsızlık konusunda ödün verilmeyeceği Avrupa devletlerine sıklıkla belirtilmişti. Örneğin Milli Mücadele sırasında Mustafa Kemal Paşa 20 Ekim 1921 tarihli Türk-Fransız Anlaşması öncesi görüşmelerde Fransız temsilcisi Franklin Bouillon'a şunları ifade etmiştir: "istiklâli tam denildiği zaman, bittabi siyasi, malî, iktisadî, adlî, askeri, harsi ve ilâ. her hususta istiklâli tam ve serbestii tam demektir. Bu saydıklarımın herhangi birinde istiklâlden mahrumiyet, millet ve memleketin, mânayi hakikisiyle bütün istiklalinden mahrumiyeti demektir". Mustafa Kemal Paşa bu sözleriyle Fransa'ya kapitülasyonlar bağlamında taviz vermeyeceğini, ülkenin iktisadi açıdan da bağımsız olması gerektiğini vurgulamıştır. ${ }^{32}$ Öte yandan bu dönemde İtilaf Devletlerine ve işgal güçlerine karşı büyük bir milliyetçi tepki ortaya çıkmıştı. Dolayısıyla yabancı şirketlere kapitülasyonları hatırlatacak imtiyazlar verilmesinden veya anlaşmalar yapılmasından kaçınılmıştı. ${ }^{33}$

1922 yılına gelindiğinde CFRNA ile Osmanlı hükümeti arasında gerçekleşen anlaşmanın yenilenmesi ile ilgili yeni bir süreç ortaya çıkmıştır.

\footnotetext{
${ }^{31}$ BCA, 230.0.0.0/57.8.1, 155 (tarihsiz).

${ }^{32}$ Mustafa Kemal, Nutuk, Cilt II (1920-1927), MEB. Yay., İstanbul 1993, s. 624; Bige Sükan, "İmparatorluktan Cumhuriyet'e Türkiye'de Yabancı Sermaye Anlayışı”, Ankara Üniversitesi Türk Inkllâp Tarihi Enstitüsü Atatürk Yolu Dergisi, Sayı 54, Bahar 2014, s. 209.

${ }^{33}$ Murat Koraltürk, Erken Cumhuriyet Döneminde Ekonominin Türkleştirilmesi, İletişim Yay., İstanbul 2011, s. 52.
} 


\section{CUMHURIYYET'IN İLK YILLARINDA İSTANBUL-BÜKRES HAVAYOLU HATTI KURULMA ÇABALARI VE İMTIYAZI MESELESI}

Çünkü şirketin Osmanlı hükümeti ile 11 Eylül 1920'de yapmış olduğu mukavelenamenin süresi 1925 y1lında dolmuş olacaktı. Bu süreçte şirketin muhatabı değişmiştir. Mevcut şartlarda Osmanlı hükümeti ile mukavele şartlarını yenilemek pek mümkün değildir. Bu nedenle CFRNA 1922'nin başlarından itibaren Hariciye Vekâleti aracılığıyla hava nakliyatı hususundaki tekliflerini Ankara hükümetine ulaştırmaya başlamıştır. Bu meyanda şirketin fenni müdürü Mösyö Revi Villomi 27 Ocak 1922'de Ankara'ya bir mektup göndererek şirketi tanıtmış, yaptığı faaliyetler hakkında bilgi vermiş ve imtiyaz talebinde bulunmuştur. Mektupta TBMM hükümetinin merkezini yirmi dört saatten az bir zamanda Paris'e bağlamanın mümkün olduğunu, bu durumun TBMM hükümetinin nazarı dikkatinden kaçmayacağını, havayolu hattının siyasi, iktisadi ve ticari açıdan önemli olduğunu vurgulamıştır. Keza CFRNA'nın hava nakliyatı hususunda Lehistan, Çekoslovakya, Macaristan, Romanya gibi devletlerle çeşitli müddetlerle imtiyaz sözleşmeleri imzaladığını da vurgulamıştır. Revi Villomi tarafından gönderilen teklif mektubunda nakdi yardım, benzin verilmesi, toprak üzerinde tesisat, ücretsiz telgraf haberleşmesi gibi şartların sağlanması halinde CFRNA'nın TBMM'yi Fransa'ya bağlamak için bir hat tesis edeceği belirtilmiştir. Ayrıca Yeşilköy'den Ankara'ya, Beyazıt'tan Mersin'e kadar bağlantılı yollar kurularak hava yolunun İstanbul'dan Tahran ve Hindistan'a doğru bağlanacağı ifade edilmiştir. ${ }^{34}$

CFRNA'nın yurt dışı hava nakliyatına yönelik önerisinin yanında dahili hava ulaşımı hususunda da Ankara hükümetine teklif verdiği anlaşılmaktadır. 3 Mart 1922 tarihli olup Revi Villomi tarafindan gönderilen mektupta şartlar maddeler halinde sıralanmıştır. Buna göre şirket "umumi menfaatlere hizmet eden" ortaklık addedilerek bu gibi müesseselere ait imtiyazlardan faydalanmak istemiştir. Revi Villomi, Türkiye'nin mali durumunun uygun olması halinde hükümetin şirkete y1llık nakdi yardım yapmasını da talep etmiştir. Teklif mektubunda TBMM hükümeti ile şirket arasında bir posta mukavelenamesinin imzalanabileceği belirtilmiştir. Havayolu hattının işletilmesi için gerekli olan levazım ve eşyaların gümrük resminden muaf olarak memlekete sokulması da istekler arasındadır. Keza sözleşmenin imzalanması halinde şirket, Türkiye sınırlarında ücret ödemeksizin tesisat kurabilme yetkisine sahip olmayı da istemiştir. Teklifte çeşitli vergi muafiyetleri de talep edilmiştir. Buna göre trenler yoluyla gerekli olan levazımın karaya çıkarılması hususunda diğer şirketlere tanınan tarifelerden CFRNA da faydalanacaktır. Yurt içinde şirketin işleri için gerekli

${ }^{34}$ BCA, 230.0.0.0./56.1.1, 13, 24-27, (27 Ocak 1922). 


\section{FEYZA KURNAZ ŞAHIN}

olan telgraf ve telsiz haberleşmesi ücretsiz olacaktır. Revi Villomi, ifade edilen bu şartların kabul edilmesi halinde şirketin fenni müdürünün, TBMM hükümeti ile teferruatı müzakere etmek için Ankara'ya gönderileceğini ifade etmiştir. Ayrıca Yeşilköy-Ankara hattının kısa bir zaman içerisinde açılacağını ve 1923'ten itibaren düzenli olarak işletebileceğini dile getirmiştir. ${ }^{35}$

CFRNA'nın TBMM hükümetinin idaresi altında bulunan bazı bölgelerde hava hatları tesisi için talep ettiği imtiyazlar, hükümet tarafindan ayrıntılı bir şekilde incelenmiştir. Posta, Telgraf ve Telefon Müdüriyeti, Revi Villomi'nin isteklerine yönelik bir tezkere hazırlamış, Maliye Vekaleti de bu tezkere üzerinden meseleyi değerlendirmiş, teklifi reddetme kararı almıştır. Maliye Vekaleti tarafindan İcra Vekilleri Heyetine gönderilen 22 Mart 1922 tarihli yazıda hükümetin talebi reddetme gerekçeleri yer almıştır. Buna göre hükümetin tekelinde bulunan telgraf ve posta hizmetinin kismen de olsa yabancı bir şirkete verilmesinin güvenlik açısından bazı sakıncalar doğuracağı kanaatine varılmıştır. Ayrıca taleplerin karşılanması halinde Posta ve Telgraf Müdürlüğünün gelirlerinin azalacağı anlaşılmıştır. Bütün bu sebeplerin yanında mevcut şartlarda imtiyaz şeklinde müsaade verilmesinin siyaseten kabul edilemeyec eği ifade edilmiştir. Bu gerekçelerle şirketin teklifi esas itibariyle reddedilmiştir. ${ }^{36}$

CFRNA, Ankara'nın tam bağımsızlık hassasiyeti nedeniyle vermiş olduğu cevaptan hoşnut olmamıştır. Ancak pes etmeye de niyetli değildir. Bu defa şirketin genel müdürü P. Dokoloryan 2 Nisan 1922'de TBMM Hükümeti İcra Vekilleri Heyeti Reisi Mustafa Kemal Paşa'ya hitaben bir mektup göndermiştir. Söz konusu mektupta Anadolu'ya gönderilen şirket yetkilisi Villomi'nin Paris'e döndüğunü, Yeşilköy (Ayastefanos) ve Ankara arasında bilahare Sivas, Erzurum, Beyazit ve Ankara, Adana, Mersin hava hatları hakkında teklif ettiği imtiyazlara ilişkin istişare yaptıklarını bildirmiştir. TBMM hükümetine yapılan teklifin kabul edilmesi halinde genel şartlara dair görüşmelerin yapılabileceğini, Fransız şirket veya bir Türk-Fransız ortaklığına sıcak baktıklarını ifade etmiştir. Bunların kabul edilmemesi halinde özel bir idare veya isim altında TBMM hükümeti ile çalışmaya hazır olduklarını dile getirmiştir. TBMM hükümeti ile Fransa hükümeti arasında

\footnotetext{
${ }^{35}$ BCA, 230.0.0.0/56.1.1, 14, (3 Mart 1338/3 Mart 1922).

${ }^{36}$ BCA, 230.0.0.0/56.1.1, 12, (22 Mart 1338/22 Mart 1922).
} 


\section{CUMHURIYYET'IN İLK YILLARINDA İSTANBUL-BÜKRES HAVAYOLU HATTI KURULMA ÇABALARI VE İMTIYAZI MESELESI}

yeniden tesis eden dostane ilişkilerin günden güne artacağ 1 temennisinde bulunulmuştur. ${ }^{37}$ Ancak şirket bu girişimden de sonuç alamamıştır.

Milli Mücadelenin sona ermesinin ardından TBMM hükümeti, 11 Şubat 1923’te Posta, Telgraf ve Telefonlar Genel Müdürü Baha Tali Bey aracılığıyla Osmanlı hükümetinin mukavele imzaladığı şirketlere tafsilatlı bir mektup göndermiştir. Söz konusu mektupta Osmanlı hükümeti ile şirketler arasında çeşitli anlaşmalar yapılmış olduğu hatırlatılmış, 16 Mart 1920'de İstanbul'un işgali sebebiyle anılan tarihten itibaren Osmanlı hükümeti ile yapılan mukavelelerin geçersiz sayıldığı bildirilmiştir ${ }^{38}$. Esasen bu kararın gerekçesi 1 Kasım 1922'de Saltanatın kaldırılmasına yönelik kabul edilen yasaya dayanmıştır. "Türkiye Büyük Millet Meclisinin hukuk-ı hakimiyet ve hükümranının mümessil-i hakikisi olduğuna dair heyet-i umumiye kararı" adlı kanun gereğince İstanbul'daki hükümet 16 Mart 1920'de sona ermiştir. Misak-1 Milli sinırları dahilinde bulunan tek hükümet TBMM hükümetidir. Dolayısıyla 16 Mart 1920'den sonra yapılan anlaşmalar TBMM tarafindan geçersiz sayılmıştır. ${ }^{39}$

Mektup CFRNA için yeni bir sorunun başlangıcı olmuştur. Zira İstanbul-Bükreş havayolu hattı için Osmanlı hükümeti ile Compagnie Franco-Roumaine de Navigation Aérienne arasında yapılan sözleşme de 16 Mart 1920 tarihinden sonra olduğundan bu mukavelename de geçersiz kalmıştır. Ancak şirket bu süreçte TBMM hükümeti ile görüşmek ve faaliyetlerine devam etmek için ciddi bir çaba harcamıştır. Örneğin CFRNA, Baha Tali Bey'in bu mektubu üzerine harekete geçmiş ve şirket müdüriyeti 23 Şubat 1923'te cevabi bir mektup göndermiştir. Anılan mektupta yeni mukavele yapmış olmaları nedeniyle Türkiye Cumhuriyeti hükümeti ile bu konuda görüşme yapmak istendiği, en kısa zaman içerisinde hava seyrüseferine başlamak arzusunda oldukları bildirilmiştir. ${ }^{40}$ Bilahare 24 Şubat 1923'te şirketin İstanbul'daki temsilcisi, Hariciye Vekaleti Dersaadet Murahhası Adnan (Adıvar) Bey'e ayrıntılı bir mektup göndermiş ve Bükreşİstanbul havayolu seferinin yeniden tesisi için gerekli olan şartların oluşturulmasını talep etmiştir. Bu meyanda dahili bir seyrüsefer şirketi tesis edilebileceği veya işletme hakkının alınması için gerekirse şirketin bir Türk

\footnotetext{
${ }^{37}$ BCA, 230.0.0.0/56.1.1, 2-11, (02.04.1338/2 Nisan 1922).

${ }^{38}$ BCA, 230.0.0.0/57.8.1, 185, (15 Teşrinisani 1339/15 Kasım 1923); BCA, 230.0.0.0/57.8.1, 149.

${ }^{39}$ Kemal Gözler, Türk Anayasa Hukuku, Ekin Kitabevi Yay., Bursa 2000, s. 53-54.

${ }^{40} \mathrm{BCA}, 230.0 .0 .0 / 57.8 .1,149$.
} 


\section{FEYZA KURNAZ ŞAHIN}

şirketi yapılabileceği dile getirilmiştir. ${ }^{41}$ Bilahare 10 Nisan 1923 'te Nafia Vekili Feyzi (Pirinççioğlu) Bey ile şirket temsilcilerinden biri arasında bir müzakere gerçekleştirilmiştir. ${ }^{42}$ Keza 2 Haziran 1923 'te şirketin İstanbul' daki mümessilleri, Dr. Adnan (Adıvar) Bey ile bağlantı kurmak için teşebbüste bulunmuşlardır. Bu çabalar sonucunda 13 Haziran 1923'te Adnan Bey'in dairesinde bir görüşme gerçekleştirilmiştir. ${ }^{43} 18$ Haziran 1923 'te tekrar bir görüşme yapılmış ise de şirket adına olumlu bir netice vermemiştir. ${ }^{44}$

Görüldüğü gibi şirket girişimlerinden sonuç alamamıştır. Bunun üzerine Fransız hükümeti ve Türk hükümetinin görüşü doğrultusunda Lozan Antlaşması sonuçlandırılmadan hat konusunda müzakerelerin sürdürülmesine gerek olmadığı yönünde tavsiye verilmiştir. Şirketin genel sekreteri dönemin politik durumundan kaynaklı olarak Doğu'da, Türk hükümetinin gözetimi altında olan İstanbul-Bükreş hava hizmetini 1923 'ün başından itibaren askıya aldığını ancak bu yılın tamamı için yalnızca TBMM hükümeti ile görüşeceğini duyurmuştur. ${ }^{45}$

Esasen Gazi Mustafa Kemal Paşa'nın yabancı sermaye konusundaki görüşleri oldukça açıktır. Zira Lozan Konferansının kesintiye uğradığı sırada toplanan 17 Şubat 1923 İzmir İktisat Kongresinin açış konuşmasında, ülkenin ihtiyac1 olması nedeniyle yabanc1 sermayeye karşı olmadıklarını, Türk kanunlarına saygılı olmak şartıyla yabancı sermayeye açık olunduğunu vurgulamıştır. Hatta Lozan Konferansının kesintiye uğradığı süreçte TBMM hükümeti, Chester Projesini gündeme getirmiştir. Bu şekilde TBMM yabancı sermayeye karşı olmadığını göstermiş ve aynı zamanda İngiltere ve Fransa'ya karşı ABD'nin desteğini almayı da planlamıştır. Bu projenin gündeme gelmesinin diğer bir nedeni ise tam bağımsız ve kalkınmış bir ülke olmak için yabancı şirketlerin olanaklarından yararlanmak istenmesidir. Ancak proje çeşitli nedenlerden dolayı hayata geçirilememiştir. ${ }^{46}$

Lozan Antlaşması sırasında Fransa eski sömürü düzenini sürdürmekten yana tavır sergilemiş ve Yeşilköy Havalimanındaki tesis ve imtiyazlarının devam etmesini talep etmiştir. Ancak Türkiye imtiyaz

\footnotetext{
${ }^{41}$ BCA, 230.0.0.0/57.8.1, 150 .

${ }^{42}$ BCA, 230.0.0.0/57.8.1, 150.

${ }^{43} \mathrm{BCA}, 230.0 .0 .0 / 57.8 .1,151$.

${ }^{44}$ BCA, 230.0.0.0/57.8.1, 153.

${ }^{45}$ BCA, 230.0.0.0/57.8.1, 185-186, (15 Teşrinisani 1339/15 Kasım 1923).

${ }^{46}$ Sükan, a.g.m., s. 209-210.
} 


\section{CUMHURIYYET'IN İLK YILLARINDA İSTANBUL-BÜKRES HAVAYOLU HATTI KURULMA ÇABALARI VE İMTIYYAZI MESELESİ}

konusunda isteksiz bir tavır sergilemiştir. ${ }^{47}$ Nihayet Lozan Antlaşmasına ek olarak konulan ve 24 Temmuz 1923'te imzalanan "Osmanl Imparatorluğunda Birtakım Ayrıcalıklara (Imtiyazlara) İlişkin Protokol ve Bildiri" metninde imtiyaz mukavelenamelerine açıklı getirilmiştir. Protokolün yedinci maddesine göre; Osmanlı Devleti ile anlaşma yapan devletlere ait ortaklıklar arasında 30 Ekim 1918-1 Kasım 1922 tarihleri arasında yapılmış olan imtiyaz sözleşmeleri, Türk hükümetinin bunları onaylaması halinde geçerli olacaktır. Türk hükümeti tarafindan bu mukaveleler onaylanmaz ise sözleşmenin beşinci maddesinde gösterilen şartlar çerçevesinde ayrıcalık sahiplerine uğradıkları maddi kayıplar için zarar giderimi verilecektir. Verilecek tazminatın miktarı bilirkişilerin vereceği raporlar doğrultusunda saptanacaktır. ${ }^{48}$

Lozan Antlaşması sonrasında Ankara hükümeti yabancı şirketlerin faaliyetlerini tanımaya başlamıştır. Zira sermaye birikimi, teknik bilgi ve beceriye ihtiyaç duyulması nedeniyle yabanc1 şirketlerin faaliyetlerine müsaade edilmiştir. Ancak yabancı sermaye konusunda oldukça temkinli davranılmıştır. Ankara hükümeti, yabancı sermayeli şirketlerin devletin egemenlik alanlarına müdahale etmesine firsat verme niyetinde değildir. $\mathrm{Bu}$ amaçla şirketlerde Müslüman-Türk unsurunun çalışmasına özel bir önem verilmiştir. $^{49}$

Lozan Antlaşmasının ardından Fransa, Yeşilköy Havalimanında hava nakliyatı ve işletimi hususunda Ankara hükümetine resmi bir teklif yapmıştır. Ancak Türkiye bu teklifi reddetmiştir. Bu şartlarda CFRNA, Yeşilköy'deki tesislerini terk etmek ve Türkiye'de kazandığ karşıya kalmıştır. ${ }^{50}$ Fakat CFRNA Türkiye'de hava işletimi haklarını kaybetmek niyetinde değildir. İstanbul-Bükreş hava hattını işletmek için muhatap bulma arayışını sürdürmüsşür. Bu arada şirket, Ankara hükümetinin kendisine verilen hak ve ayrıcalıklara saygılı olacağı noktasında endişeler taşıdığını da ifade etmiştir. Nihayet Adnan Adıvar'ın İstanbul'a dönüşüne kadar Dersaadet Murahhas Vekilliği yapan ${ }^{51}$ General Selahattin Adil Paşa meseleyle ilgilenmiştir. Selahattin Adil Paşa, Türkiye-Avrupa arasındaki

${ }^{47}$ BCA, 230.0.0.0/57.8.1, 186, (15 Teşrinisani 1339/15 Kasım 1923).

${ }^{48}$ Seha Meray, Lozan Barış Konferansı Tutanaklar Belgeler, İkinci Takım Cilt II, Konferansta İmzalanan Senetler (30 Ocak ve 24 Temmuz 1923), 3. Bask1, Yap1 Kredi Yayınları, İstanbul 2001, s. 102.

${ }^{49}$ Koraltürk, a.g.e., s. 252-253.

${ }^{50}$ BCA, 230.0.0.0/57.8.1, 186, (15 Teşrinisani 1339/15 Kasım 1923).

${ }^{51}$ BCA, 30.18.1.1/7.15.17, (17 Nisan 1923). 


\section{FEYZA KURNAZ ŞAHIN}

ilişkileri yeniden tesis etmenin gerekli olduğunu düşünerek 18 Eylül 1923'te şirket temsilcilerini kabul etmiştir. Aynı dönemde Dr. Adnan Bey ise şirketin Yeşilköy'deki uçakları ile levazımını tahliye etmesi gerektiğini bildirmiştir. ${ }^{52}$ Bu sırada şirketin umum müdürü Mösyö Betard, Paris'ten Ankara'ya gelerek görüşme yapmak istemiş ancak bunun bir fayda sağlamayacağı kendisine bildirilmiştir. Aynı tarihlerde şirketle Türkiye Cumhuriyeti hükümeti arasında tahliye işlemleri ile ilgili bir anlaşmazlıktan kaynaklı gerginlik ortaya çıkmıştır. Şirket yetkilileri en sonunda Hariciye Vekili ve Başbakan İsmet Paşa'ya telgraf çekerek gerek İstanbul-Bükreş hattını yeniden açmak ve gerekse hava posta ulaşımında hizmet etmek üzere bir Türk şirketi kurmak niyetiyle Ankara'ya gelmek istediklerini dile getirmişlerdir. ${ }^{53}$ Şirket, Türkiye ile ilişkilerini geliştirmek, İstanbul-Bükreş hattında faaliyet göstermek niyetinde olduğunu her şartta ifade etmiştir. ${ }^{54}$

CFRNA, Türkiye'deki haklarını anlatmak için Adnan Bey ile yeniden bağlantıya geçmiş ve bu yolla isteklerini ve projelerini Ankara hükümetine iletmeye çalışmıştır. Bütün bu çabaların ardından hükümet CFRNA ile yeni bir sözleşme yapmak için müzakereleri sürdürmeyi kabul etmiştir. ${ }^{55} C F R N A$ 1924'ün başından itibaren hükümetle olan temaslarını artırmıştır. CFRNA İstanbul-Bükreş-Paris hava hattının yeniden faaliyete geçirilmesi için Türk hükümetinin destek ve yardımını beklediğini, projenin Ankara'ya uzatılması hususunda gerekli düzenlemeleri yapmaya hazır olduğunu, hükümetin sözleşme yapmayı kabul etmesi halinde derhal maddeleri görüşmek üzere tam yetki sahibi bir temsilci göndereceğini dile getirmiştir. ${ }^{56}$

Öyle anlaş1lyyor ki CFRNA, hava hatları konusunda sahip olduğu imtiyazı kaybetmemek için hükümetin güvenini sağlamaya çalışmıştır. Zira yetkili kişilere gönderdiği mektuplarda şirketin merkezi, sermaye miktarı, hedeflerine kadar her adım ayrıntısıyla anlatılmıştır. CFRNA, İstanbul'u bütün Avrupa başkentlerine, Ankara'yı da Batı'ya bağlayan hava hatları oluşturmayı arzu ettiğini belirtmiştir. ${ }^{57}$

\footnotetext{
${ }^{52} \mathrm{BCA}, 230.0 .0 .0 / 57.8 .1,151$.

${ }^{53} \mathrm{BCA}, 230.0 .0 .0 / 57.8 .1,152$.

${ }^{54} \mathrm{BCA}, 230.0 .0 .0 / 57.8 .1,153$.

${ }^{55}$ BCA, 230.0.0.0/57.8.1, 186, (15 Teşrinisani 1339/15 Kasım 1923).

${ }^{56}$ BCA, 230.0.0.0/57.8.1, 186, (15 Teşrinisani 1339/15 Kasım 1923).

${ }^{57}$ BCA, 230.0.0.0/57.8.1, 185, (15 Teşrinisani 1339/15 Kasım 1923).
} 


\section{CUMHURIYYET'IN İLK YILLARINDA İSTANBUL-BÜKRES HAVAYOLU HATTI KURULMA ÇABALARI VE İMTIYYAZI MESELESİ}

\section{Cumhuriyet'in İlk Yıllarında Havayolunda Fransiz-Alman Rekabeti ve Bükreş-İstanbul Havayolu Hattı İmtiyazı Meselesi}

Cumhuriyet'in ilk y1llarında milli ekonomi ilkeleri benimsenirken bir yandan da yabancı sermayenin ülkenin ihtiyacı olan alanlarda yatırım yapmasına izin verilmiştir. Bu meyanda su, elektrik, tramvay, telefon, demiryolu gibi alanlarda faaliyet gösteren şirketlerle yeni sözleşmeler imzalanmıştır. ${ }^{58}$ Yabancı sermayenin Türkiye'de bazı imkânlardan yararlanabilmesi için de çeşitli şartlar getirilmiştir. Bu kapsamda ortaklıkların Türk yasalarına göre hareket etmesi, Türk dilini kullanması ve Türk işgücü istihdam etmesi mecbur tutulmuştur. ${ }^{59}$

Cumhuriyetin kurulmasından sonra Ankara hükümeti havayolu nakliyatının başlaması ve Türkiye'de bir uçak fabrikası kurulması için şirketlerle görüşmeler yapmaya başlamıştır. Havacılık konusunda faaliyet gösteren şirketler de bu konuda oldukça istekli olmuşlardır. ${ }^{60}$ Örneğin CFRNA direktörü, iki uçağını hava yoluyla Bükreş’e göndermek amacıyla izin talebi vesilesi ile Türkiye-Fransa arasında uçuş mukavelesi yapılması için temennilerini dile getirmiştir. Bu anlamda 2 Haziran 1923 tarihinde Hariciye Vekaleti Dersaadet Murahhası Adnan (Adıvar) Bey'e hitaben bir mektup gönderilmiştir. Mektupta şirketin Yeşilköy'de bulunan iki uçağını Bükreş'e gönderme yetkisi istenmiştir. Keza Türkiye ile Fransa arasında hava trafiğine ilişkin bir anlaşmanın yapılması hususunda Türkiye'den olumlu bir cevap bekledikleri belirtilmiştir. ${ }^{61}$

Öyle anlaş1lyyor ki bu dönemde Almanlar da hava nakliyatı hususunda Türkiye ile görüşme girişimlerine başlamışlardır. Örneğin Alman menfaatlerini himayeye memur İsveç sefiri, Alman Hariciye Nezaretinden aldığı bir telgraf üzerine 27 Kasım 1923'te Türkiye'nin Almanya ile münasebet tesisi arzusunda olup olmadığını sormuştur. Bu arada Ankara'da yapılan hava taşımacılığı ile ilgili görüşmelere Almanlar da katılmıştır. $\mathrm{Bu}$ toplantıya Fransızlar ilk etapta iştirak etmemişlerse de Almanların katılımı üzerine harekete geçmişlerdir. $\mathrm{Bu}$ meyanda Mösyö Sojeni'nin girişimiyle CFRNA temsilcisi Mösyö Betard tam yetkiyle Ankara'ya gönderilmiştir. ${ }^{62}$

\footnotetext{
${ }^{58}$ Sükan, a.g.m., s. 212-213.

${ }^{59}$ Koraltürk, a.g.e., s. 107.

${ }^{60}$ BCA, 230.0.0.0/57.8.1, 148 (tarihsiz).

${ }^{61}$ BOA, Hariciye Nezareti İstanbul Murahhaslı̆̆ (HR.ìM.), 47/43, 1-2, (2 Haziran 1923).

62 BOA, HR.IM., 22/170, 1-2, (28.11.1339/28 Kasim 1923); BOA, HR.IM., 21/14, 11.9.1339

(11 Eylül 1923), 1; BOA, HR.IM., 18/104, (02.05.1339/2 Mayıs 1923).
} 
Almanların havayolu nakliyatına olan ilgileri sonraki yıllarda da devam etmiştir. Örneğin Türkiye Cumhuriyeti hükümeti, 1924 yılından itibaren hava nakliyatı ve uçak fabrikası kurulması için şirketlerle müzakerelere başlamıştır. Hatta 15 Haziran 1924 tarihli İcra Vekilleri Heyeti toplantısında alınan karar doğrultusunda şirketlerle görüşülecek esasları belirlemek üzere Erkanı Harbiye Umumiye Reisi ile Müdafaa-i Milliye, Nafia ve Ticaret Vekaletlerinden oluşan bir encümen oluşturulmuş, bu kurulun tespit edeceği şartlar çerçevesinde şirketlerle temas kurulmuştur. Şirketlerle görüşmek için de Müdafaa-i Milliye, Nafia ve Ticaret Vekaletinden bir temsilcinin katıldığı ayrı bir komisyon oluşturulmuştur. ${ }^{63}$ Bu noktada Türkiye Cumhuriyeti hükümeti şirketlere, hava nakliyatının başlaması, uçak motoru dahil olmak üzere bütün uçak malzemelerinin imkanlar dahilinde Türkiye'de yapılmasını teklif etmiştir. ${ }^{64}$

Karş1lıklı görüşmelerin ardından şirketler hava nakliyatı için Türkiye Cumhuriyeti hükümetine müracaatta bulunmuşlardır. $\mathrm{Bu}$ müracaatlar hükümet tarafindan tetkik edilmiştir. Yapılan müracaatlarda Alman Junkers şirketi ile Fransız CFRNA'nın rekabet içinde olduğu görülmüştür. Her iki şirket de tekliflerini içeren mektubu komisyona iletmişlerdir. Alman Junkers adına hareket eden görevli Terliyam ve CFRNA adına talepte bulunan Mösyö Jean Schlicklin'in hava nakliyatı için hükümete ulaştırdıkları teklifler Ticaret Vekili Hasan Bey'in reisi olduğu komisyon tarafindan incelenmiştir. Junkers ve Franco-Romen şirketlerinin teklifleri arasında Türkiye'de uçak motoru üretmekle ilgili bir esasın bulunmadığı görülmüştür. Hatta her iki şirket temsilcisi de tayyarecilikte topluca manyetolu olarak devir ve hareket eden motorların Türkiye'de kısa bir müddet zarfında imal edilmesinin mümkün olamayacağını ve böyle bir teklifte bulunamayacaklarını dile getirmişlerdir. Ancak hükümetin şirketlerle sözleşmeye oturmak için sunduğu ön şart ülkenin uçak ihtiyacını temin etmek ve bu konuda yabancılara bağımlı olmaktan kurtulmaktır. Dolayısıyla hükümetin en büyük isteği Türkiye'de bir uçak fabrikası ve diğer tesislerin kurulmasıdır. Bunu gerçekleştirmek için uçakların en önemli aksamını oluşturan motorların Türkiye' de imal edilmesi istenmiş ise de şirketler yaptıkları tekliflerde bunun mümkün olamayacağını ifade etmişlerdir. ${ }^{65}$ Bunun üzerine hükümet hava nakliyatı alanında mukavele yapmak isteyen şirketlere, Türkiye'nin asıl amacının ordunun ihtiyacı olan

\footnotetext{
${ }^{63}$ BCA, 30.18.01.01/10.29.12, 1, (15 Haziran 1340/15 Haziran 1924).

${ }^{64}$ BCA, 30.18.01.01/10.29.12, 2, (Haziran 1340/1924).

${ }^{65}$ BCA, 30.18.01.01/ 10.41.18, 1, (27.08.1340/27 Ağustos 1924).
} 


\section{CUMHURIYYET'IN İLK YILLARINDA İSTANBUL-BÜKRES HAVAYOLU HATTI KURULMA ÇABALARI VE İMTIYAZI MESELESİ}

hava savunma sanayisini kurmak olduğunu, uçak motoru da dahil olmak üzere uçak yedek parçalarının mümkün olduğu ölçüde Türkiye'de üretilmesinin istendiğini belirtmiştir. CFRNA ve Junkers firmalarına Türkiye' de tesis edilecek uçak fabrikaları hakkında üç ay zarfinda kesin ve açıklayıcı bir teklif yapmaları için yeniden hak verilmiştir. Aksi halde yani şirketlerin uçak fabrikası kurma ile ilgili hükümetin isteklerini yerine getirememeleri halinde hava nakliyatı ile ilgili çalışmaların durdurulacağı bildirilmiştir. ${ }^{66}$

Cumhuriyet döneminde hava nakliyatı ile ilgili rekabet içerisinde olan diğer bir devlet ise İtalya'dır. İtalya da Türkiye Cumhuriyeti'nin Avrupa ve dünya ile ilişkiler kurma ve iletişim sağlama çabasını görmüştür. $\mathrm{Bu}$ amaçla İtalya da havayolu nakliyatı hususunda imtiyaz alabilmek için çeşitli tekliflerle Ankara hükümetine başvurmuştur. Bu noktada İtalyan Sociata Anonima Aero Espresso Italiana (AEI) şirketinin faaliyetleri dikkate değerdir. $A E I$, Türkiye Cumhuriyeti hükümeti ile yurt dışı ticari hava nakliyatı hususunda ilk mukavelename imzalayan şirket olmuștur. Sözleșme İcra Vekilleri Heyetinin 27 Ağustos 1924 tarihli toplantısında kabul edilerek onaylanmıştır. Şirket, Brindisi-İstanbul arasında bir havayolu bağlantısı kurulması için faaliyet göstermiştir. ${ }^{67}$ Cumhuriyet döneminde ilk mukavele İtalyan şirketle yapılmasına rağmen ilk uçuş $A E I$ 'ya ait değildir. $C F R N A$ sözleşmeyi daha geç imzalamasına rağmen İstanbul-Bükreş arasındaki uçuş Brindisi-İstanbul hattından daha önce gerçekleşmiştir. ${ }^{68}$

\section{Compagnie Internationale de Navigation Aérienne (CIDNA)-} Beynelmilel Havaî Seyrüsefer Şirketi) ile Mukavelename İmzalanması

Fransız CFRNA ile hava nakliyatı hususundaki sonuç odaklı görüşmeler 1924 yılının ilk aylarında başlamıştır. Esasen şirket için 1923 yılı farklı gelişmelere sahne olmuş idi. Çünkü yukarıda da ifade edildiği üzere TBMM hükümeti, İstanbul'un işgal tarihi olan 16 Mart 1920'den itibaren Osmanlı hükümeti ile sözleşme imzalayan şirketlerin mukavelelerini tanımadığını açıklamıştı. CFRNA'nın Osmanlı hükümeti ile imzalamış

\footnotetext{
${ }^{66}$ BCA, 30.18.01.01/10.41.18, 1-2, (27.08.1340/27 Ağustos 1924).

${ }^{67}$ Haytoğlu, a.g.m., s. 82-84; Akansel Yalçınkaya, "Türk Havayolu Taşımacılığı Sektörünün Tarihsel Gelişimi ve Devlet Müdahaleleri (1933-2006)”, Hacettepe Üniversitesi Cumhuriyet Tarihi Araştırmaları Dergisi (CTAD), Y11 15, Sayı 29, Bahar 2019, s. 407.

${ }^{68}$ BCA, 230.0.0.0/56.4.7, (29 Nisan 1926); BCA, 230.0.0.0/56.4.11, (11 Eylül 1926).
} 


\section{FEYZA KURNAZ ŞAHIN}

olduğu mukavele 11 Eylül 1920 tarihliydi. ${ }^{69}$ Şirket mektuptan hemen sonra sahip olduğu hakları kaybetmemek için TBMM hükümeti ile bağlantıya geçti ve havacılık faaliyetlerine devam etmek için ciddi bir çaba harcadı. Bunun için şirket mümessilleri Dr. Adnan Bey, Nafia Vekili Feyzi Bey gibi yetkililerle müzakerelerde bulundu ancak bu görüşmelerden olumlu bir sonuç alamadı ${ }^{70}$ Çünkü Türkiye bu dönemde tam bağımsızlık ilkesini ön plana almış, yapılan sözleşmelerin kapitülasyonları hatırlatacak şekilde tek taraflı imtiyazlar tarzında olmasından kaçınmıştır. Bu nedenle özellikle Avrupalı şirketlerle gerek hava nakliyatı ve gerekse diğer alanlarda mukavelename imzalarken son derece temkinli hareket edilmiş, tam da bu nedenle hükümet yapmış olduğu sözleşmelere "verilen hakkın bir imtiyaz olmadığına" dair madde eklemiştir. ${ }^{71}$ Öte yandan ticari hava nakliyatında Türkiye'nin güvenliği de ön planda tutulmuştur. $\mathrm{Bu}$ alanda şirketlerle anlaşmalar yapilırken Müdafaa-i Milliye Vekaletinin anlaşmaya onay vermesi öncellenmiş, şirketlere arazi tahsisi, uçuş güzergahları, telsiz haberleşmeleri ve hatta şirketlerin yapmayı taahhüt ettiği hangarların hangi malzeme ile yapılacağı hususunda vekaletin görüşleri dikkate alınmıştır. ${ }^{72}$

CFRNA, Cumhuriyet' in ilan edilmesinin ardından tekliflerini sürekli yinelemiş, nihayet şirket 1924 yılından itibaren muhatap bulmaya başlamıştır. Zira Nafia Vekaletinden Başvekalete gönderilen 27 Aralık 1923 tarihli yazıda Paris-Bükreş-İstanbul hava hattının Türkiye arazisine isabet eden kısmında uçak ile nakliyat yapmak amaciyla imtiyaz talebinde bulunan CFRNA'nın müdürü Betard tarafindan yapılan teklifin, şirketle müzakere edilmesi, anlaşılması halinde mukavele ve şartnamelerin hazırlanması, incelenmesi ve tasdik edilmesi için izin istenmiştir. ${ }^{73}$

CFRNA adıyla faaliyet gösteren şirket hava nakliyatı alanında imtiyaz çabası içerisine girmiş ise de Türkiye Cumhuriyeti hükümeti ile mukavelenameyi bu ad altında imzalayamamıştır. Çünkü şirketin 1 Ocak 1925'ten itibaren ad1 Compagnie Internationale de Navigation Aérienne (CIDNA)-Beynelmilel Havaî Seyrüsefer Şirketi olarak değiştirilmiştir. Şirket bundan sonraki faaliyetlerini bu isim altında gerçekleştirmiştir. ${ }^{74} \mathrm{Bu}$ nedenle

${ }^{69}$ BCA, 230.0.0.0/57.8.1, 185, (15 Teşrinisani 1339/15 Kasım 1923); BCA, 230.0.0.0/57.8.1, 149.

${ }^{70}$ BCA, 230.0.0.0/57.8.1, 149; BCA, 230.0.0.0/57.8.1, 150-153.

${ }^{71} \mathrm{BCA}, 230.0 .0 .0 / 57.6 .1$.

${ }^{72}$ BCA, 30.18.01.01/22.79.13, 1-3, (18 Aral1k 1926).

${ }^{73}$ BCA, 230.0.0.0/56.1.1, 1, (27 Kanunuevvel 1339/27 Aralı 1923).

${ }^{74}$ BCA, 230.0.0.0/57.6.1. 


\section{CUMHURIYYET'IN İLK YILLARINDA İSTANBUL-BÜKRES HAVAYOLU HATTI KURULMA ÇABALARI VE İMTIYAZI MESELESI}

şirketin Türkiye Cumhuriyeti hükümeti ile mukavelesi yeni adı olan CIDNA ile imzalanmıștır.

a) Mukavelenamenin Imzalanmast

Türkiye Cumhuriyeti hükümeti ile CIDNA arasında yapılan görüşmeler 1925 yılı Temmuz ayında hızlanmıştır. $\mathrm{Bu}$ tarihlerde mukavelename esasları da taraflar arasında yapılan müzakerelerle tespit edilmiştir. Görüşmeler Türkiye Cumhuriyeti adına Nafia Vekili İstanbul Mebusu Süleyman Sırrı (Aral) Bey ile CIDNA adına şirketin Türkiye şubesi müdürü ve yetki sahibi Jean Schlicklin arasında sürdürülmüştür. Taraflar yolcu ve posta nakliyatı için müsaade verilmesine dair mukavelename şartlarını da görüşmüşlerdir. Keza posta nakliyatı ve mukavelename ekleri de hazırlanmıştır. Hazırlanan bu sözleşme ve ekleri Nafia Vekaleti tarafından tetkik edilmiş ve 19 Temmuz 1925 tarihinde İcra Vekilleri Heyetine sunulmuştur. İcra Vekilleri Heyetinin 29 Temmuz 1925 tarihli toplantısında mukavelename esasları görüşülmüş ve onaylanmıştır. ${ }^{75}$

Türkiye, İstanbul-Bükreş havayolu hattının oluşturulması için görüşmeler yaptığ1 "Avrupa Merkezi Beynelmilel Hattı Havaîsinin Bükreş İstanbul Arasında İşlemesine Dair Mukavelenameyi" 17 Ağustos 1925 tarihinde imzalamıştır. Sözleşme, Türkiye Cumhuriyeti adına Nafia Vekili İstanbul Mebusu Süleyman Sırrı Bey ile merkezi Paris'te bulunan ve eski adı Franco-Romen Nakliyat-ı Havâye Şirketi olan bilahare Beynelmilel Havâ̂ Seyrüsefer Şirketi adını alan şirket adına imza yetkisine sahip, işletmenin Türkiye şubesi müdürü Jean Schlicklin arasında imzalanmıştır. Mukavelenamenin maddeleri şu şekildedir ${ }^{76}$

Mukavelenamenin birinci maddesine göre, Türkiye Cumhuriyeti hükümeti, merkezi Fransa'nın Paris kentinde bulunan, eski adı FrancoRomen Nakliyat-ı Havaîye Şirketi olup yeni adı Beynelmilel Havaî Seyrüsefer Şirketi'ne İstanbul-Bükreş hava hattını düzenli olarak işletmesi ve bununla ilgili müesseseleri kurması için müsaade ve ruhsat vermiştir. Ruhsat ve müsaade yolcu, eşya ve posta naklini ihtiva etmektedir. Sözleşme tasdik edildiği tarihten itibaren yirmi yıl geçerli olacaktır. Ancak altı ay evvel talep edilmek şartıyla on yılın sonunda taraflardan herhangi biri mukavelenamenin yedinci maddesinin hükümleri kapsamında sözleşmeyi feshetme yetkisine

${ }^{75}$ BCA, 30.18.01.01/14.47.15, 1, (29 Temmuz 1341/29 Temmuz 1925).

${ }^{76}$ BCA, 230.0.0.0/57.6.1. 


\section{FEYZA KURNAZ ŞAHIN}

sahiptir. ${ }^{77}$ Bilahare 14 Aralık 1927 tarihinde İcra Vekilleri Heyetinin kararıyla sözleşmenin birinci maddesinde düzenleme yapılmıştır. $\mathrm{Bu}$ anlamda maddenin sonuna "tesisat ve binaların hava yolculuğu hizmetine verileceği ve başka bir amaçla kullanılmayacağ $l$ " esası eklenmiştir. ${ }^{78}$

Mukavelenamenin ikinci maddesinde bu hakkın bir imtiyaz olmadığına vurgu yapılmıştır. Buna göre sözleşme ve eklerine uygun olarak Türkiye Cumhuriyeti hükümeti tarafından verilen müsaade ve ruhsat hiçbir şekilde imtiyaz ve inhisar mahiyetinde değildir. Mukavelename hükümlerinin sadece Bükreş-İstanbul hattına mahsus olduğu vurgulanmıştır. ${ }^{79}$

Uçuşlar ile ilgili zaman aralıkları üçüncü maddede yer almıştır. Buna göre şirket sözleşmenin onaylandığ 1 tarihten itibaren dört aylık bir süre içerisinde uçuşa uygun olmayan kötü hava koşulları istisna olmak üzere her istikamette Şubat'ın on beşinden Nisan başına ve Ekim başından Kasım ayının on beşine kadar haftada en az üç ve Nisan başından Ekim ayı sonuna kadar da her gün gidiş-dönüş seferleri düzenlemeye mecburdur. Esas itibariyle seferler kış mevsiminde yani on beş Kasım'dan on beş Şubat'a kadar tatil olunabilecektir. Öyle olmakla beraber şirket düzenini taahhüt etmemek şartıyla hava koşullarının uygun olduğu zamanlarda bu mevsimlerde de seferler düzenlemeye hazır olduğunu beyan etmiştir. ${ }^{80}$ Üçüncü maddeye bilahare 14 Aralık 1927 tarihinde İcra Vekilleri Heyeti kararıyla Nisan ve Ekim ayları arasında yapılacak seferlerde Pazar günleri uçuş yapılmayabileceği esası eklenmiştir. ${ }^{81}$

Dördüncü madde uçuş emniyeti ile ilgili tedbirleri içermektedir. Buna göre şirket hat üzerinde seferlerin düzenli ve emniyetli olarak yapılması için yeterli miktarda uçak kullanmayı taahhüt etmiştir. Şirketin hat üzerinde işleteceği uçakların yük, sürat, emniyet, telgraf ve diğer gerekli olan hususları on dokuzuncu maddede belirtilen fenni komisyon tarafindan tespit edilmiştir. Beşinci maddeye göre şirketin uçakları için İstanbul'da bulunduracağı yedek alet ve edevat iki yıl müddetle ulaşımı düzenli olarak sağlayacak miktarda

\footnotetext{
${ }^{77}$ BCA, 230.0.0.0/57.6.1, 7-8, s. 3-4, (17 Ağustos 1341/17 Ağustos 1925).

${ }^{78}$ BCA, 230.0.0.0/57.6.1, s. 1; BCA, 230.0.0.0/61.25.2, 95, s. 2, (14 Kanunuevvel 1927/14 Aralık 1927).

${ }^{79}$ BCA, 230.0.0.0/57.6.1, 7-8, s. 3-4, (17 Ağustos 1341/17 Ağustos 1925).

${ }^{80}$ BCA, 230.0.0.0/57.6.1, 7-8, s. 3-4, (17 Ağustos 1341/17 Ağustos 1925).

81 BCA, 230.0.0.0/57.6.1, s. 1, (14 Kanunuevvel 1927/14 Aralik 1927); BCA, 230.0.0.0/61.25.2, 93-94, (23 Kanunusani 1928/28 Ocak 1928).
} 


\section{CUMHURIYYET'IN İLK YILLARINDA İSTANBUL-BÜKRES HAVAYOLU HATTI KURULMA ÇABALARI VE IMTTIYAZI MESELESİ}

olacak ve bu miktar tarafların tayin edeceği uzmanlar tarafindan tespit edilecektir.

Şirkete tahsis edilecek arazi ile ilgili hususlar mukavelenamenin altıncı maddesinde ifade edilmiştir. Buna göre şirketin hizmet edebilmesi amacıyla yapacağı tesisler için gerekli olan arazi ücretsiz olarak tahsis edilecektir. Şirkete verilecek bu arazi fenni komisyon tarafından tespit edilecek ve uygunluğu onaylanacaktır. Aynı zamanda Müdafaa-i Milliye Vekaletinin de arazinin uygun olduğunu tasdik etmesi gereklidir. Bu onaylar alındıktan sonra kararlaştırılan şartlar doğrultusunda şirket hazırlıklarını yapacaktır. Bundan sonra kargir (taş ve tuğladan veya siman arme denilen yapıştırmada kullanılan kimyasal dolgu malzemesi ile) bir iki hangar, atölye, mağazalar, bekleme salonları, yazıhane, polis ve gümrük daireleri, benzin, yağ için toprak altı su mahzenleri, hava gözlem yeri, Müdafaa-i Milliye Vekaletince müsaade edildiği takdirde telsiz telgraf mevkileri ve kısacası hattın işlemesine lazım olan her şeyi tasdik edildikten sonra hükümet inşaata müsaade edecektir. ${ }^{82} \mathrm{Bu}$ madde, Müdafaa-i Milliye Vekaleti ile Erkan-1 Harbiye Umumiye Riyasetinin hangarların demir olması isteği doğrultusunda $^{83} 19$ Aralık 1926'da İcra Vekilleri Heyetinin kararıyla düzeltilmiş ve hangarların kargir yerine portatif yapılması, duvarlarının saçlarla çevrilmesi ve kapılarının bilyeli yatak üzerinde kolaylıkla açılır kapanır bir surette demirden inşa edilmesi kararlaştırılmıştır. ${ }^{84}$

Mukavelenamenin sona ermesi halinde oluşan şartlara karşı alınacak tedbirler yedinci maddede esasa bağlanmıştır. Buna göre Türk hükümeti arzu ettiği takdirde, birinci maddede açıklandığı şekilde, gerek on yıldan sonra ve gerekse mukavelenamenin bitiminin ardından şirketin Türkiye'de bulunan bütün bina, alet ve edevatını, yedek ve ihtiyat malzemelerini, eşya ve uçaklarını şu esaslar doğrultusunda satın alabilecektir. ${ }^{85}$

1) On yılın sonunda şirket faaliyete devam etmek istediği halde mukavele hükümet tarafindan tek taraflı olarak feshedilir ise CIDNA uçak, levazım, yedek ve ihtiyat eşyasını satmakta serbest olacaktır. Fakat şirket,

\footnotetext{
${ }^{82}$ BCA, 230.0.0.0/57.6.1, 7-8, s. 4, (17 Ağustos 1341/17 Ağustos 1925).

${ }^{83}$ BCA, 30.18.01.01/22.79.13, 2-3, (14 Kanunuevvel 1926/14 Aralık 1926).

${ }^{84}$ BCA, 230.0.0.0/57.6.1, 34-38; BCA, 230.0.0.0/61.25.2, 101-105, (19 Kanunuevvel 1926/19 Aralık 1926); BCA, 30.18.01.01/22.79.13, 004, (19 Kanunuevvel 1926/19 Aralık 1926); BCA, 30.18.01.01/22.79.13, 1, (21 Kanunuevvel 1926/21 Aralık 1926).

${ }^{85}$ BCA, 230.0.0.0/57.6.1, 7-8, s. 4-5, (17 Ağustos 1341/17 Ağustos 1925).
} 


\section{FEYZA KURNAZ ŞAHIN}

binaları bunların mâl oldukları faturalar ile tahakkuk eden bedelden yüzde yirmi noksanı ile hükümete satmaya mecburdur.

2) Onuncu yılın sonunda şirket faaliyetini kendi isteği ile durdurursa ya da mukavelename müddeti sona ererse ilk maddeden farklı bir ișlem yapılacaktır. Şöyle ki hükümet şirketin mallarını satın almak için teklif yaparsa şirket, bütün uçak, levazım, yedek eşyasını ve binalarını hükümete satmaya mecbur olacaktır. Fakat her iki durumda da hükümet tarafindan satın alınacak uçakların adedi Bükreş-İstanbul hattında işleyenlerin yarısından ibaret olacaktır. Birinci şıkta emval-i menkule hariç, ikinci şıta ise emval-1 menkule dahil olmak üzere bütün bu malların değeri biri hükümet, diğeri şirket tarafindan tayin olunacak iki uzman kişi tarafindan tespit edilecektir. Anlaşmazlık halinde satın alma fiyatı temyiz mahkemesi reisi tarafindan tayin edilecek bir hakem tarafindan belirlenecektir. Yedinci maddenin bu fikrasina bilahare 14 Aralık 1927 tarihinde bir ekleme yapılmıştır. İkinci fikrada “....hükümet ve şirket tarafindan tayin olunacak iki ehil kişi tarafindan tespit edilecektir" cümlesinin devamına "Ancak tespit edilecek satın alma fiyatı yüzde otuz eksiğiyle şirkete verilecektir. İki ehil kişinin uyuşması halinde satın alma yüzde otuz eksiği şirkete ödenmek şartıyla temyiz mahkemesi reisi tarafindan tayin edilecek bir hakem tarafindan takdir edilecektir" ibaresi eklenmiştir. ${ }^{86}$

Mukavelenamenin sekizinci maddesi şirketin faaliyetlerini düzenli olarak yapabilmesi için şirkete tanınan muafiyetleri ortaya koymaktadır. Buna göre şirketin taahhüt ettiği işleri yerine getirmek için hükümet tarafindan kendisine aşağıda ifade edilen muafiyetler verilecektir;

1) Şirketin beşinci madde gereğince ithal etmek mecburiyetinde olduğu yedek aletlerle uçakları gümrük resminden muaf olacaktır.

2) Şirketin sadece hava hattı hizmetlerinde kullanmak için ithal edeceği gerekli malzemeler [esans, yă̆], aseton, vernik ve diğer maddeler ithalat resmine tabi olacaktır. Bütün muameleler hükümetin ilgili memurları tarafından kontrol edilecektir. Kontrolün daha etkili olmasını sağlamak için şirket mağaza ve toprak altı mahzenlerini görevli memurların nezaret ve teftişine açık bulunduracaktır. ${ }^{87}$

${ }^{86}$ BCA, 230.0.0.0/57.6.1, 34, s. 1; BCA, 230.0.0.0/61.25.2, 96-97, (14 Kanunuevvel 1927/14 Aralık 1927).

${ }^{87}$ BCA, 230.0.0.0/57.6.1, 7-8 s. 5, (17 Ağustos 1341/17 Ağustos 1925). 


\section{CUMHURIYYET'IN İLK YILLARINDA İSTANBUL-BÜKRES HAVAYOLU HATTI KURULMA ÇABALARI VE IMTIYAZI MESELESI}

Dokuzuncu maddeye göre, şirket bütün işlemlerinde Türkiye'deki kanunlara tabi olacaktır. Hükümet, hava hatlarını ve şirketin kurumlarını Nafia Vekaleti tarafindan tayin edilen bir komiser aracılığıyla kontrol etme hakkına sahiptir. Şirket teftişi kolaylaştırmaya mecburdur ve bunun için hükümet veznesine yıllık beş yüz lira ödeme yapmak zorundadır. Şirketin hükümetle haberleşmesi Türkçe olacaktır. ${ }^{88}$

Çalıştırılacak personelin uyruğu meselesi onuncu maddede bir esasa bağlanmıştır. Buna göre şirket pilot ve makinist hizmetlerinde Bükreşİstanbul hattındaki memurların ve müstahdemlerin üçte birine denk olacak şekilde Türk tebaası istihdam edecektir. ${ }^{89}$ Esasen sözleşmede yer alan bu husus Cumhuriyet döneminde uygulanan ekonominin Türkleştirilmesi politikasının tezahürüdür. Zira bu dönemde yabancı sermayeli olup Türkiye'de bazı imtiyazlara sahip şirketlerde Müslüman-Türk kökenli işgücünün istihdam edilmesi temel şartlardan birisi olmuştur. Bu sebeple Ankara hükümeti ile yabancı şirketler arasında yapılan mukavelelerde işgücünün Türkleştirilmesine yönelik esaslar ön plana alınmıştır. Bu dönemde yabancı şirketlerle yapılan sözleşmeler incelendiğinde örneğin elektrik, su, havagazı, tramvay hizmetleri veren şirketlerle yapılan sözleşmelerde istihdam ettikleri yabancı ve gayrimüslim çalışanların işten çıkartılarak yerlerine Müslüman-Türklerin istihdam edildiği görülmektedir. ${ }^{90}$

Uçuş hattında çalışacak Türk memurları hükümet seçecektir. Memurlar şirket tarafından Fransa veya Türkiye'deki uçak fabrikalarında veyahut şirketin eğitim kurumlarında eğitim görecektir. Memurların eğitim süresi ve hizmeti, hattaki diğer memurların hukuk ve vazifeleri ile aynı olacaktır. Memurlar, Fransa veya Türkiye hükümeti tarafından tayin edilecek bir memurun da hazır bulunacağı teori ve pratik iki aşamalı sınavda başarılı olmaları halinde hizmet yapmaya başlayacaklardır. ${ }^{91}$ Mukavelenin bu maddesine 14 Aralık 1927 tarihinde bir ekleme yapılmıştır. Buna göre şirket hava kuvvetleri emrinde veya diğer bir askeri müessesede çalışmış herhangi

${ }^{88}$ BCA, 230.0.0.0/57.6.1, 7-8, s. 5-6, (17 Ağustos 1341/17 Ağustos 1925).

${ }^{89}$ BCA, 230.0.0.0./57.6.1, 35, s. 2; BCA, 230.0.0.0/61.25.2, 97, (14 Kanunuevvel 1927/14 Aralık 1927).

${ }^{90}$ Koraltürk, a.g.e., s. 229-232.

${ }^{91}$ BCA, 230.0.0.0/57.6.1, 7-8, s. 6, (17 Ağustos 1341/17 Ağustos 1925). 


\section{FEYZA KURNAZ ŞAHIN}

bir şahsı çalıştırmak isterse kişi müesseseden ayrılmış olsa dahi kurumun izni olmaksızın hizmete alamayacaktır. ${ }^{92}$

Şirket uçaklarının hareket cetvelleri, nakliye ücretleri, tarifeleri, devlet memurlarına gösterilecek indirim, kolaylıklar ve ücretsiz biletlerin miktarı her yıl Nafia Vekaleti ile şirket arasında anlaşmalı olarak tayin ve tespit edilecektir (madde on bir). Mukavelenin on ikinci maddesine göre hükümet havacılığa ait plan ve projeleri hazırlamak için şirkete ihtiyaç duyması halinde CIDNA fenni teşkilatını, maliye ve tüccarlarını ve diğer bütün vesaitini hükümetin emrine vermek zorundadır. ${ }^{93}$

Sözleşmenin on üçüncü maddesinde şirketin hava nakliyatı için gerekli olan haberleşme tesisleri üzerindeki hak ve yetkileri esasa bağlanmıştır. Buna göre şirket kendisine tahsis olunan arazi üzerinde, hava gözetleme mevkileriyle Müdafaa-i Milliye Vekaletince müsaade edildiği takdirde telsiz, telgraf ve ahize istasyonları tesis edebilecektir. Bu istasyonlar belli sınırlar dâhilinde Türk hükümetine ait istasyonlarla ilişkili olacaktır. Ancak haberleşme istasyonu tesisi yasaktır. Şirket ahize ve telsiz istasyonunu Türk telsiz istasyonlarına telefonla bağlayabilecektir. Hava gözlem mevkileri gözlem bilgilerini hükümetin belirlediği bütün makamlara vermeye mecburdur. Hükümet bu istasyonları kontrol etme hakkına sahiptir. Şirket de bu kontrol için gerekli olan kolaylığı göstermeye mecburdur. ${ }^{94}$

Mukavelenamenin on dördüncü maddesi kaza ve hasar olması durumunda Türkiye Cumhuriyeti hükümetinin yardımını esasa bağlamaktadır. Buna göre kaza ve hasar ortaya çıkması halinde hükümet tehlikede bulunan veya hareket edemeyen uçağa ve tehlikeye maruz kalan diğer binek vasıtalarına yardım etmeyi ve kolaylık sağlamayı taahhüt etmiştir. ${ }^{95}$

Hava nakliyatı hususunda uluslararası anlaşmaların esasları çerçevesinde alınacak tedbirler ise on beşinci maddede yer almıştır. Buna göre Türkiye Cumhuriyeti hükümeti, şirkete telsiz telgraf, hava gözlem mevkileri, kartografi, kaza durumunda yardım sağlamayı ve bu tür durumlarda Paris'te kabul edilen 13 Ekim 1919 tarihli Beynelmilel Hava

92 BCA, 230.0.0.0./57.6.1, 35, s. 2; BCA, 230.0.0.0/61.25.2, 97, (14 Kanunuevvel 1927/14 Aralık 1927).

${ }_{93}$ BCA, 230.0.0.0/57.6.1, 7-8, s. 6, (17 Ağustos 1341/17 Ağustos 1925).

${ }^{94}$ BCA, 230.0.0.0/57.6.1, 7-8, s. 6, (17 Ağustos 1341/17 Ağustos 1925).

${ }^{95}$ BCA, 230.0.0.0/57.6.1, 7-8, s. 6-7, (17 Ağustos 1341/17 Ağustos 1925). 


\section{CUMHURIYYET'IN İLK YILLARINDA İSTANBUL-BÜKRES HAVAYOLU HATTI KURULMA ÇABALARI VE IMTIYAZI MESELESI}

Nakliyatı Sözleşmesinin esaslarını kabul etmiştir. Taraflar mukavele şartlarına uymayı karşılıklı olarak taahhüt etmişlerdir. Bu anlamda imzalanan sözleşmenin uluslararası mukaveleye aykırı olmayacağı belirtilmiştir. ${ }^{96}$

Taraflar arasında yaşanacak anlaşmazlıklara dair çözümler mukavelenamenin on altıncı maddesinde bir esasa bağlanmıştır. Buna göre mukavelename ile eklerinin hükümleri ve uygulanma tarzına bağlı olarak Türkiye Cumhuriyeti ile şirket arasında ortaya çıkacak her türlü anlaşmazlık biri hükümet diğeri şirket tarafından tayin edilecek iki uzman kişiden oluşan bir komisyon tarafından giderilecektir. Anlaşmazlık halinde temyiz mahkemesi reisi tarafından tayin edilecek bir hakem kesin olarak anlaşmazlığı halledecektir. ${ }^{97}$

On yedinci maddede ifade edildiği şekliyle şirket nakledeceği mektup ve posta paketleri hakkında Posta Müdüriyeti Umumiyesi ile ek olarak bir mukavelename imzalayacaktır. Birinci maddede adı geçen muhtelif memleketlere gönderilecek paketler için Posta, Telgraf ve Telefon Müdüriyeti Umumiyesi tarafindan tespit edilen ağırlık veya boyutu aşan paketlerin havayolu ile nakli amaciyla "hava ile nakil hissesi" olarak herhangi bir ücret ödenmeyecektir. Bunların ağırlığından meydana gelen gelir tamamen şirkete ait olacaktır. ${ }^{98}$

Bilet ve posta gönderileri için açılacak acentelerle ilgili esaslar sözleşmenin on sekizinci maddesinde ele alınmıştır. Buna göre şirket bilet satmak ve Türkiye posta idaresinin kabul etmediği kolileri kabul etmek için Türkiye'nin en önemli merkezlerinde acenteler tesis etmek yetkisine sahiptir. Ancak şirket İstanbul'dan başka yerlerde açacağı acentelikler için Nafia Vekaletinden ayrica ruhsat almak zorundadır. ${ }^{99}$

Sözleşmede ifade edilen çeşitli esasların teferruatı ve özellikle takip edilecek yol ortaklaşa kararlaştırılacaktır. Buna göre yardım meydanları, hava gözlem, telsiz, telgraf mevkilerinin tesisi, Türk memurların teorik ve pratik eğitimleri ve ihtisas sahibi olmaları için alınan kararlar birlikte alınacaktır. Ayrıca alet ve yedek edevatın gerekliliği ve miktarı ile alakalı teknik sorunlar, hükümet uzmanlarıyla sözleşmenin imza tarihinden itibaren bir ay içerisinde şirketin Ankara'daki fen murahhası tarafindan anlaşmalı olarak tespit

${ }^{96}$ BCA, 230.0.0.0/57.6.1, 7-8 s. 7, (17 Ağustos 1341/17 Ağustos 1925).

${ }^{97}$ BCA, 230.0.0.0/57.6.1, 7-8, s. 7, (17 Ağustos 1341/17 Ağustos 1925).

${ }^{98}$ BCA, 230.0.0.0/57.6.1, 7-8, s. 7, (17 Ağustos 1341/17 Ağustos 1925).

${ }^{99}$ BCA, 230.0.0.0/57.6.1, 7-8, s. 7, (17 Ağustos 1341/17 Ağustos 1925). 


\section{FEYZA KURNAZ ŞAHIN}

edilecektir. Şirket bir ay içerisinde temsilci göndermediği takdirde mukavele hiçbir işlem yapmaya gerek kalmaksızın feshedilecektir (madde on dokuz). ${ }^{100}$

Mukavelenin geçerli olduğu süre boyunca şirketin merkezi Paris olacaktır. Bununla beraber şirket Ankara'da tam olarak yetkilendirilmiş bir şube açmak zorundadır. Şirket her durumda Bükreş ile İstanbul arasında bir Türk şebekesi tesis edecek ve bu şebekenin müdüriyeti İstanbul'da Yeşilköy'de bulunacaktır. Türkiye şubesini temsil eden şirket müdür veya memuru şirketin Paris'teki idare meclisi tarafindan tam olarak yetkili olduğuna dair resmi evrakı göstermeye mecburdur (madde yirmi). ${ }^{101} \mathrm{Bu}$ madde 14 Aralık 1927'de değiştirilmiş ve "şirket Ankara'da tam olarak yetkilendirilmiş bir şube tesisine mecburdur" esası maddeden çıkarılmıştır. ${ }^{102}$

Son maddede sözleşmenin Ankara'da imza ve teati edildiği tarihten itibaren geçerli olacağı ifade edilmiştir (madde yirmi bir). Mukavelenin sonunda şartları kabul ederek imzalayanların Süleyman Sırrı Bey ile Mösyö Jean Schlicklin olduğu belirtilmiştir. Mukavelenamenin imzalanması sırasında Nafia Müdüriyeti Umumiyesi Muavini Nafiz Bey ve Nafia Müdüriyetinden bir dosya memuru da hazır bulunmuştur. ${ }^{103}$

Mukavelenameye ek olarak 17 Ağustos 1925 tarihinde posta nakliyatıyla ilgili on maddeden oluşan bir sözleşme de imzalanmıştır. Söz konusu sözleşme de Nafia Vekili Süleyman Sırrı Bey ile şirket namına Mösyö Jean Schlicklin tarafından imzalanmıştır. ${ }^{104}$ Sözleşmenin birinci maddesinde, Türkiye Posta ve Telgraf Müdüriyeti tarafindan şirkete verilecek adî veya taahhütlü mektuplar, açık haberleşme varakaları, haber, gazete, iş mektupları, ticari eşya numuneleri, matbuat evrakı, kıymeti mukadderli mektup, kıymetli ve kıymetsiz posta paketleri ve posta çantalarının İstanbul-Bükreş arasında uçaklarla nakledileceği belirtilmiştir. İkinci madde posta çantaları ve posta paketlerinin azami ağırlığına ilişkin esasları tespit etmiştir. Posta çantalarının azami ağırlığı yüz kiloyu, posta paketleri kırk beş santimetreyi geçemeyecektir. Üçüncü maddeye göre hava yolundan gönderilecek bütün posta gönderileri İstanbul postanesinde birikecek, şirket tarafından tayin edilen bir memur imza karşılığında gönderileri teslim alacaktır. Posta

\footnotetext{
${ }^{100}$ BCA, 230.0.0.0/57.6.1, 7-8, s. 7-8, (17 Ağustos 1341/17 Ağustos 1925).

${ }^{101}$ BCA, 230.0.0.0/57.6.1, 8, 8, (17 Ağustos 1341/17 Ağustos 1925).

102 BCA, 230.0.0.0./57.6.1, 35, s. 2; BCA, 230.0.0.0/61.25.2, 97, (14 Kanunuevvel 1927/14 Aralık 1927).

${ }^{103}$ BCA, 230.0.0.0/57.6.1, 8, (17 Ağustos 1341/17 Ağustos 1925).

${ }^{104}$ BCA, 230.0.0.0/57.6.1, 8, (17 Ağustos 1341/17 Ağustos 1925).
} 


\section{CUMHURIYYET'IN İLK YILLARINDA İSTANBUL-BÜKRES HAVAYOLU HATTI KURULMA ÇABALARI VE İMTIYAZI MESELESI}

nakliyatına dair sözleşmenin diğer maddelerinde yer alan esaslar ise şu şekildedir; uçaklarla nakledilecek posta gönderilerinin ücretleri mukavelenameye ekli bir tarife cetvelinde açıklanmıştır. Postaların zayii durumunda şirket bundan sorumludur. Şirketin telsiz istasyonları Müdafaa-i Milliye Vekaletinin izniyle kurulacaktır. Telsiz istasyonlarında istihdam edilecek memurlar mutlaka Posta, Telgraf ve Telefon Müdüriyeti tarafindan tayin edilecek ve memurların maaşları şirket tarafından ödenecektir. ${ }^{105}$

CIDNA ile imzalanan 17 Ağustos 1925 tarihli mukavelenamenin posta nakliyatı dışında bir eki daha bulunmaktadır. Bu ek uçaklarla ilgili teknik meseleleri içermektedir. Söz konusu ekte, şirketin İstanbul-Bükreş hava hattında kullanacağı uçakların özellik ve kabiliyetleri, motor ve kanat özellikleri, ağırlı̆̆ı, sürati, irtifası, yedek stoku, hava istasyonunda bulunduracağı malzemeler listesi ve bu malzemelerin cinsi ile Türk havacı, makinist ve motorcuların eğitilmesi için esaslar belirtilmiştir. ${ }^{106}$

Sözleşmeye 14 Aralık 1927 tarihinde iki madde daha ilave edilmiştir. Buna göre mevcut yirmi birinci madde, yirmi üçüncü madde olmuştur. Yirmi birinci madde "hava nakliyatı tesisi için yapılan bilumum inşaatın ikmal olunduğu şirket tarafindan ihbar olunduktan sonra Nafia Vekaleti tarafindan oluşturulmuş bir fen komisyonu vasitasıly söz konusu inşaatın tasdik edilmiş planlara ve fenni şartlara uygunluğu incelenerek komisyonun yapacă̆ı rapor üzerine vekaletçe kabul muamelesi icra edilecektir. Bu muayene komisyonunun bütün masraflarl şirkete ait olacaktır" ş̧eklindedir. ${ }^{107}$ Mukavelenameye eklenen yirmi ikinci madde şirketin Sofya hattında da hava nakliyatı yapabilmesine ilișkindir. Buna göre mukavelede mevcut olan İstanbul-Bükreş arasında hava hattı işletilmesine ait ruhsat, İstanbul-Sofya hattını kapsayacak şekilde genişletilmiştir. Bu hatta kullanılacak uçakların adedinin yarısı kadarı Yeşilköy'de hangarda bulundurulacaktır. Şirketin yedek olarak bulundurmaya mecbur olduğu eşya ve malzeme, ekli listede verilmiştir. Hükümet istediği zaman, şirket aralıksız olarak Sofya hattındaki

105 BCA, 230.0.0.0/57.6.1, 46-51, (17 Ağustos 1341/17 Ağustos 1925); BCA, 230.0.0.0/61.25.2, 75-78.

106 BCA, 230.0.0.0/57.6.1, 25-33, (26 Eylül 1341/26 Eylül 1925); BCA, 230.0.0.0/61.25.2, 8193

107 BCA, 230.0.0.0./57.6.1, 36, 3; BCA, 230.0.0.0/61.25.2, 99, (14 Kanunuevvel 1927/14 Aralık 1927). 


\section{FEYZA KURNAZ ŞAHIN}

hava ulaşımını tatile mecbur olacak ve bundan dolayı hiçbir zarar talebinde bulunamayacaktır. ${ }^{108}$

\section{b) CIDNA'nın Faaliyetleri ve İsim Değişikliği}

CIDNA'nın uçuşlarının 1926'nın Mart ayından itibaren başladığı anlaşılmaktadır. Esasen şirketle yapılan mukavelename gereğince, sözleşme imzalandıktan dört ay sonra uçuşlar başlamak durumunda idi. Ancak imzaların atıldığ tarih 1925 yılının Ağustos ayı olduğundan dört ay sonrası Aralık ayına yani uçuşların kış şartlarından dolayı tatil edildiği döneme denk gelmiştir. Zira sözleşmenin üçüncü maddesinde yer alan esasa göre 15 Kasım15 Şubat arasında uçuşlar tatil olabilmektedir. Bu şartlar dâhilinde şirket, İstanbul-Bükreş arası uçuşlarını Mart 1926'dan itibaren yapmaya başlamıştır. Arşiv verilerinde İstanbul-Bükreş havayolu hattının 1926 yılına ait uçuş cetvelleri de yer almaktadır. Burada şunu ifade etmek gerekir ki Brindisiİstanbul arasında sefer yapmak için hükümetle 1924 y1lında mukavele yapan Sociata Anonima Aero Espresso Italiana şirketinin ${ }^{109}$ mukaveleyi daha erken imzalamış olmasına rağmen CIDNA'dan daha sonra uçuşlara başladığı anlaşılmaktadır. ${ }^{110}$

1929 Dünya Ekonomik Buhranı şirketlerin hava nakliyatını etkilemiş, uçak kaldırmak için yakıt bulmakta sıkıntılar yaşanmıştır. Bu nedenle şirketler mukavelename esaslarına göre depolarda yedek olarak bulundurmaları gereken benzini harcamak zorunda kalmışlardır. Türkiye Cumhuriyeti hükümeti bu konuda şirketleri uyarmıştır. Örneğin İstanbulBükreş Havayolu hattını işleten CIDNA ve Aero Espresso Italiana uçak şirketleri ile yapılan mukavelename gereğince şirketler hükümet emrine verilmek üzere kırkar ton benzin ve dörder ton yağ bulundurmak zorundadırlar. Ancak benzin ve yă depolanmasında bazı aksaklıkların yaşandığ 1 anlaşılmaktadır. Zira 24 Temmuz 1930 tarihli bir İcra Vekilleri Heyeti Kararnamesine göre epey bir müddet benzin satın alınamaması yüzünden depolarda bulunması gereken benzin ve yağ harcanmıştır. Hükümet bu depoların dolu olmasına özel bir önem vermiş ve bu doğrultuda İcra Vekilleri Heyetinin 24 Temmuz 1930 tarihli toplantısında adı geçen şirketlerin depolarında daima bulundurmaları gereken benzin ve yağın 40.800 lira tutarında dışardan satın alınmasına karar verilmiştir. ${ }^{111}$

108 BCA, 230.0.0.0./57.6.1, 35, 2; BCA, 230.0.0.0/61.25.2, 97, (14 Kanunuevvel 1927/14 Aralık 1927).

${ }^{109}$ Haytoğlu, a.g.m., s. 83.

${ }^{110}$ BCA, 230.0.0.0/56.4.7, (29 Nisan 1926); BCA, 230.0.0.0/56.4.11, (11 Eylül 1926).

${ }^{111}$ BCA, 30.18.1.2/13.52.6, 1-3, (24 Temmuz 1930). 


\section{CUMHURIYYET'IN İLK YILLARINDA İSTANBUL-BÜKRES HAVAYOLU HATTI KURULMA ÇABALARI VE İMTIYYAZI MESELESİ}

Öte yandan uçaklar ile ilgili yedek malzeme tedariki de oldukça önemli bir husus olmuştur. Bu nedenle CIDNA ile yapılan mukavelenamede malzemenin tedarik usulleri belli esaslara bağlanmıştır. Buna göre şirket, hükümet emrine verilmek üzere bazı malzemeleri elinde bulundurmak zorundadır. Ancak bu yedek malzemeler Türkiye'de bulunmadığından dışarıdan tedarik edilmesi gerekmiştir. Bunun üzerine hükümet malzemelerin yurt dışından sağlanması için zaman zaman kararnameler çıkarmıştır. Örneğin İcra Vekilleri Heyetinin 18 Mart 1931 tarihli toplantısında söz konusu malzeme ve yedek parçaların yurt dışından alınmasına karar verilmiştir. $\mathrm{Bu}$ malzemelerin tamamı Marsilya, Paris ve Belgrad'dan alınmıştır. Malzeme listesi incelendiğinde uçak motorları ve uçaklar için gerekli olan yedek parça ve malzemeler olduğu anlaşılmaktadır. ${ }^{12}$

Şirketler zaman içerisinde teknolojik gelişmelere paralel olarak uçak modellerini değiştirmeyi uygun bulmuşlardır. Böyle durumlarda sözleşme gereğince hükümete teklif vermişlerdir. Hükümet oluşturduğu bir komisyon aracılığıyla bu teklifi değerlendirmiș ve mukavelenamenin ilgili maddeleri değiştirilmiştir. Örneğin 14 Mart 1931 tarihli olup Nafia Vekaletinden Başvekalete gönderilen bir yazı buna örnek gösterilebilir. Yazıda CIDNA ile imzalanan 17 Ağustos 1925 tarihli mukavelename ekinin birinci maddesine uygun olarak İstanbul-Bükreş ve İstanbul-Sofya arasında şirketin uçurduğu ve hangarlarda yedek olarak bulundurduğu 46 tipi uçaklar yerine daha gelişmiş modellerin alınması söz konusu olmuştur. Teknolojik yenilikleri takip etmek amacıyla uçakların 420 beygir kuvvetinde Jupiter motoru ile donatılmış 29 tipindeki Potez ve 230 kuvvetinde Salmson motoru ile donatılmış 32 tipindeki Potez uçakları ile değiştirilmesinin teklif edildiği ifade edilmiştir. Hükümet, şirketin bu teklifini değerlendirmek ve incelemek amaciyla bir komisyon oluşturmuştur. Erkan-1 Harbiye'den memur edilmiş olan heyet ile şirket temsilcilerinin katılımıyla bir inceleme yapılmıştır. $\mathrm{Bu}$ inceleme sonucunda 46 tipindeki uçaklar yerine şirketin bu hatlarda 32 ve 29 tipindeki Potez uçaklarını kullanmasının uygun olacağına karar verilmiştir. İhtiyat olarak da hangarlarda 29 tipindeki Potez uçaklarının muhafaza edilmesi kararlaştırılmıştır. Uçaklara ait motor ve malzemenin özellik ve adetleri de tespit edilerek bunların tedariki hususunda karar alınmıştır. Kararlar Nafia Meclisi tarafindan da incelenerek şirketin bu teklifi hangi şartlar altında yapabileceği hakkında ayrıca bir maddenin ilave edilmesi gerektiği beyan edilmiştir. Keza şirketle imzalanan mukavelenamenin yirmi

${ }^{112}$ BCA, 30.18.1.2/18.18.6, 1-33, (18 Mart 1931). 


\section{FEYZA KURNAZ ŞAHIN}

ikinci maddesi ve bu maddeyi tamamlayan mukavele ekinin birinci maddesi tadil edilerek maddenin sureti ve yedek malzemelerin listesi Başvekalete takdim edilmiştir. ${ }^{13}$

CIDNA ile imzalanan 17 Ağustos 1925 tarihli mukavelenamenin yirmi ikinci maddesinde yapılan değişiklik şu şekildedir:

"İ̧̧bu mukavelenamede mevcut ve İstanbul ile Bükreş arasinda hattı havainin işletilmesine ait ruhsat, İstanbul-Sofya hattına da teşmil edilmiş olup, bu hatlarda kullanılacak 29, 32 tipindeki Potez tayyareleri adedinin yarlsı kadar miktarda 29 Potez tipinde olmak üzere Yeşilköy'deki hangarlarda ihtiyat olarak bulunduracakttr. $\dot{I S S ̧}_{s}$ bu tayyareleri şirket ayda bir defaya mahsus olmak üzere kendi işlerinde kullanabilecektir. Zaruret halinde ve muvakkat mahiyetinde olarak şirket bu tiplerden başka ancak bir tayyare kullanabilir. Şirketin yedek olarak bulundurmaya mecbur olduğu edevat ve malzeme listede muharrerdir. Şu kadar ki hükümet istediği vakit, şirket müstemirren Sofya hattindaki seyrüseferi havaiyeyi tadile mecbur olup bundan dolayı hiçbir zarar ziyan talebine hakk olmayacaktır". ${ }^{114}$

Uçak modellerini değiştirmek isteyen şirketlerin zor durumda kalmaması için Nafia Meclisinin kararı ile mukavelenameye bir madde eklenmesine karar verilmiştir. Buna göre teknolojik gelişmeleri takip edebilmek amacıyla uçaklarını değiştirmek isteyen şirket, bu konudaki teklifini "yeni sene için kabul edilecek şekilde ve yeni senenin girmesinden altı ay önce Nafia Vekâletine vermek zorundadır" esası kabul edilmiştir. ${ }^{115}$ Şirketin yapacağı bu gibi teklifler Nafia Vekaleti, askeri taraf ve şirket tarafından tayin edilecek uzmanlar tarafından müşterek olarak tetkik edilecek ve yeni yıl için kabul edilen uçak sistemleri ve yedek malzeme miktarı ve cinsleri tespit edilecektir. ${ }^{116} \mathrm{Bu}$ vasıflar arasında uçağın motor gücü ve tipi, uzunluğu, kanat açıklığı, ağırlığı, ilave depo kapasitesi, deniz seviyesindeki sürati, irtifası v.b. özellikler cetvellerle belirlenmiştir. İhtiyat uçakları için yedek malzeme listesi de hazırlanmış ve bu şartlar üzerinden şirketin teklifi değerlendirilmiştir. ${ }^{117}$ Nafia Vekaletinin mukavelenamenin maddelerinde yapılan değişiklikle ilgili teklifleri İcra Vekilleri Heyetinin 1 Nisan 1931

\footnotetext{
${ }^{113}$ BCA, 30.18.01.02/19.22.9, (14 Mart 1931).

${ }_{114}$ BCA, 30.18.01.02/19.22.9, 4, (14 Mart 1931).

${ }_{115}$ BCA, 30.18.01.02/19.22.9, 4, (14 Mart 1931).

${ }^{116}$ BCA, 30.18.01.02/19.22.9, 4, 11, (14 Mart 1931).

${ }^{117}$ BCA, 30.18.01.02/19.22.9, 5, 10, (14.03.1931).
} 


\section{CUMHURIYYET'IN İLK YILLARINDA İSTANBUL-BÜKRES HAVAYOLU HATTI KURULMA ÇABALARI VE İMTIYYAZI MESELESİ}

tarihli toplantısında görüşülmüş ve sözleşmeye eklenecek ve düzeltilecek maddeler aynen kabul edilmiştir. ${ }^{118}$

Öyle anlaşılıyor ki 1929 Dünya Ekonomik Buhranı uçak seferlerini de etkilemiş ve her gün icra edilen İstanbul-Bükreș seferleri geçici bir müddet için haftada üç defaya indirilmiştir. Bu hususta Nafia Vekili tarafindan 25 Ağustos 1931 tarihinde Başvekalete gönderilen yazıda, sanayide olduğu gibi ticarette de hüküm süren iktisadi buhranın ulaşımı da olumsuz yönde etkilediği dile getirilmiştir. Bu nedenle CIDNA tarafından her gün yapılmakta olan İstanbul-Bükreş seferlerinin geçici bir süre için haftada üç defaya indirilmesi hususunda teklif yapıldığı bildirilmiştir. Bu talep Erkan-1 Harbiye Riyasetine ve Dahiliye Vekaletine sorulmuş ve alınan cevaplarda seferlerin haftada üç güne indirilmesinde bir mahsur olmadığ ifade edilmiştir. Şirket, yapılan bu değişikliğin mukavelename gereğince hükümet emrine depolarda hazır bulundurmaya mecbur olduğu uçak motoru, benzin ve yedek malzemeler üzerinde bir değişiklik yaratmayacağına dair taahhütte bulunmuştur. Ayrıca yolcu ve ticaret mallarının ortaya çıkması halinde sefer günlerinden hariç diğer günlerde de ek seferler konulabileceği kararlaştırılmıştır. Bunun yanında gün aşırı yapılan İstanbul-Bükreş, İstanbulSofya seferlerinin Belgrad'da birleşmesi nedeniyle İstanbul'un Orta ve Batı Avrupa ile irtibatının gidişte olduğu gibi dönüşte de temin edileceği yine şirket tarafindan taahhüt edilmiştir. Nafia Vekili seferlerin azaltılması hususunda yapılan son değişiklikler nedeniyle daha evvelden yapılmış olan mukavelenamenin maddelerinde değişiklik yapılmasını gerekli görmüştür. Bunun için mukavelenamenin üçüncü maddesinde değişikliğe gidilmiştir. ${ }^{119}$ Vekiller Heyetinin 14 Eylül 1931 tarihli toplantısında uçak seferlerinin haftada üç güne indirilmesi onaylanmıştır. ${ }^{120}$

İstanbul-Bükreş ve İstanbul-Sofya arasında uçuş yapması için ruhsat verilmiş olan CIDNA bir müddet sonra Avrupa'da faaliyet gösteren bazı uçak şirketleri ile birleşerek Air France adını almıştır. Bu kapsamda şirketin hak ve borçları da Air France şirketine devredilmiştir. Bunun üzerine İcra Vekilleri Heyetinin 11 Ekim 1934 tarihli toplantısında şirketin sözleşmelerinde yazan adının da Air France olarak değiştirilmesi kabul edilmiştir. ${ }^{121}$

\footnotetext{
118 BCA, 30.18.01.02/19.22.9, (1 Nisan 1931).

${ }^{119}$ BCA, 30.18.01.02/23.64.7, 2, (25 Ağustos 1931).

${ }^{120}$ BCA, 30.18.01.02/23.64.7, 1, 7, (25 Ağustos 1931).

${ }^{121}$ BCA, 30.18.01.02/48.69.19, (11 Ekim 1934).
} 


\section{FEYZA KURNAZ ŞAHIN}

\section{Sonuç}

Çalışmanın temel amacı Cumhuriyet döneminde İstanbul-Bükreş ticari havayolu nakliyatının başlatılmasına yönelik çabaları irdelemek olarak tanımlanmış idi. Bu meyanda arşiv kaynaklarından elde edilen veriler özellikle I. Dünya Savaşı'nın ardından ticari havayolu nakliyatı alanında ciddi bir rekabetin olduğunu ortaya koymaktadır. Zira bu dönemde hava nakliyatı ciddi bir stratejik egemenlik aracına dönüşmüştür. Özellikle iki savaş arasında hava nakliyatı diplomatik-askeri ittifakların korunmasının vazgeçilmez bir anahtarı olmuştur. Fransa bu konuda oldukça hırslı bir görüntü sergilemiştir. Adeta "düşmanlardan önce yer fethetmek" arzusuyla Paris'i İstanbul'a hatta Uzak Doğu'ya bağlamak için hayli uğraş vermiştir.

Havayolu nakliyatı hususunda faaliyet gösteren Fransız, Alman ve İtalyan şirketler 1922'den itibaren TBMM hükümeti ile bağlantıya geçerek Osmanlı hükümeti döneminde elde ettikleri imtiyazları yeniden elde etmek için ısrarcı olmuşlardır. Çalışmada belirgin olarak ortaya çıkan diğer bir husus ise TBMM'nin bu imtiyaz taleplerine 1924'e kadar kayıtsız kalmasidır. Çünkü Türkiye bu dönemde tam bağımsızlık ilkesini ön plana almıştır. Yapılan sözleşmelerin kapitülasyonları hatırlatacak şekilde tek taraflı imtiyazlar şeklinde olmasından kaçınılmıştır. Bu nedenle özellikle Avrupalı şirketlerle gerek hava nakliyatı ve gerekse diğer alanlarda mukavelename imzalarken son derece temkinli hareket edilmiştir. Tam da bu nedenle yapmış olduğu hava nakliyatı ile ilgili sözleşmelere "verilen hakkın bir imtiyaz olmadı̆̆ına" dair madde eklenmiştir. Öte yandan ticari hava nakliyatında Türkiye'nin güvenliği de ön planda tutulmuştur. Bu alanda şirketlerle anlaşmalar yapılırken Müdafaa-i Milliye Vekaletinin anlaşmaya onay vermesi öncellenmiştir.

Türkiye Cumhuriyeti hükümeti hava nakliyatı hususunda yabanc1 şirketlerin tekliflerini esas olarak 1924'ten itibaren dikkate almaya başlamıştır. Çünkü Türkiye, Avrupa ve dünya ile bağlantılarını sağlıklı bir şekilde kurmak durumunda olmuştur. Hükümet hava nakliyatı ile savunma sanayisini farklı görmemiş ve şirketlerle sözleşmeye oturmak için uçak fabrikası kurmak ve uçak motorlarını Türkiye'de üretmek şartını öne sürmüştür. $\mathrm{Bu}$ şekilde hükümet, ordunun uçak ihtiyacını temin etmeye ve hava savunma sanayisinde yabancılara bağımlı olmaktan kurtulmaya çalışmıştır. 


\section{CUMHURIYYET'IN İLK YILLARINDA İSTANBUL-BÜKRES HAVAYOLU HATTI KURULMA ÇABALARI VE İMTIYYAZI MESELESİ}

Çalıșmada ortaya çıkan diğer bir husus ise hava nakliyatı alanında yabancı sermaye ile işbirliğine gidilmiş olmasıdır. Cumhuriyetin ilk yıllarında bir yandan milli ekonomi ilkeleri benimsenirken bir yandan da ülkenin ihtiyacı olan alanlarda yabancı sermayenin yatırım yapmasına izin verilmiştir. Sadece havacılık alanında değil su, elektrik, tramvay, telefon, demiryolu gibi alanlarda faaliyet gösteren şirketlerle yeni sözleşmeler imzalanmıştır. Yabanc1 sermayenin Türkiye'de faaliyet göstermesi için bazı şartlar öne sürülmüsşür. Bu meyanda ortaklıkların Türk yasalarına göre hareket etmesi, Türk dilini kullanması ve Türk işgücü istihdam etmesi mecbur tutulmuştur.

Türkiye Cumhuriyeti hükümeti Avrupa ile havayolu bağlantısını sağlıklı bir şekilde kurmak amacıyla havayolu nakliyatı alanında faaliyet gösteren İtalyan ve Fransız şirketleriyle ilerleyen süreçte mukaveleler imzalamıştır. İlk sözleşme 1924'te Sociata Anonima Aero Espresso Italiana (AEI) şirketi ile yapılmıştır. Şirket İstanbul-Atina-Brindisi hattındaki uçuşlarına 1926 yılında başlayabilmiştir. Çalışmanın konusunu oluşturan İstanbul-Bükreș hattı müsaadesi ise 17 Ağustos 1925 'te Fransız Compagnie Franco-Roumaine de Navigation Aérienne -CFRNA (Franco-Romen Havầ Seyrüsefer Şirketi)'nin isim değiştirmiş hali olan Compagnie Internationale de Navigation Aérienne -CIDNA (Beynelmilel Havaî Seyrüsefer Şirketi)'ne verilmiştir. Şirket İtalyan şirketten sonra mukavele imzalamasına rağmen uçuşlarına bu şirketten daha önce Mart 1926'da başlamıştır. Şirket bu tarihten itibaren mukavele şartları doğrultusunda faaliyetlerine devam etmiştir. Ancak 1929 Dünya Ekonomik Buhranı havayolu nakliyatını da sıkıntıya soktuğu için şirket haftalık seferlerini azaltmak durumunda kalmıştır. CIDNA 1934'te Avrupa'daki bazı havayolu şirketleriyle birleşerek Air France adını almıştır.

\section{KAYNAKÇA}

\section{Arşiv Kaynakları}

Cumhurbaşkanlı̆̆ı Devlet Arşivleri Başkanlı̆̆ı Osmanlı Arşivi (BOA) Babıali Evrak Odası Divan Kalemi Mukavelenameler (A.DVN.MKL.), 69/30, 1, 1, 2 (H. 02.01.1340/5 Eylül 1921).

Dâhiliye Nezareti İdare-i Umumiye Kalemi (DH.İ.UM.), 16-5/1-46, 1-1, (5 Eylül 1336/5 Eylül 1920). 


\section{FEYZA KURNAZ ŞAHIN}

DH.I.UM., 16-5/1-46, 2-4, (26 Ağustos 1920); 16-5/1-46, 3-1, (11 Teşrinievvel 1338/11 Ekim 1922).

Hariciye Nezareti İstanbul Murahhaslı̆̆ (HR.IM.), 47/43, 1-2, (2 Haziran 1923).

HR.IM. , 18/104, (02.05.1339); 21/14, 11.9.1339, 1; 22/170, 1-2, (28.11.1339/28 Kasim 1923).

Irade Dosya Usulü (I.DUIT.), 22/28, 1-1, (H.24.12.1338/8 Eylül 1920); 22/28, 1-2, 2-1, 3-1, 3-2 (H.24.12.1338/8 Eylül 1920).

Meclis-i Vükelâ Mazbataları (MV.), 217/18, (H.13.01.1338/8 Ekim 1919); 252/94, (H.24.12.1338/8 Eylül 1920).

\section{Cumhurbaşkanlığı Devlet Arşivleri Başkanlığı Cumhuriyet Arşivi (BCA)}

230.0.0.0./56.1.1, 13, 24-27, (27 Ocak 1922).

230.0.0.0./57.6.1, 35, 2; 230.0.0.0./57.6.1, 36, 3 .

230.0.0.0/56.1.1, 1, (27 Kanunuevvel 1339/27 Aral1k 1923); 230.0.0.0/56.1.1, 12, (22 Mart 1338/22 Mart 1922); 230.0.0.0/56.1.1, 14, (3 Mart 1338/3 Mart 1922); 230.0.0.0/56.1.1, 2-11, (02.04.1338/2 Nisan 1922); 230.0.0.0/56.1.1, 24-27 (27 Ocak 1922).

230.0.0.0/56.4.11, (11 Eylül 1926).

230.0.0.0/56.4.7, (29 Nisan 1926).

230.0.0.0/57.6.1, 25-33, (26 Eylül 1341/26 Eylül 1925); 230.0.0.0/57.6.1, 34, s. $1 ; 230.0 .0 .0 / 57.6 .1,34-38$.

230.0.0.0/57.6.1, 46-51, (17 Ağustos 1341/17 Ağustos 1925).

230.0.0.0/57.6.1, 7-8, s. 3-8, (17 Ağustos 1341/17 Ağustos 1925).

230.0.0.0/57.6.1, 8, 9, (17 Ağustos 1341/17 Ağustos 1925).

230.0.0.0/57.6.1, s. 1, (14 Kanunuevvel 1927/14 Aralık 1927).

230.0.0.0/57.8.1, 140-153, 155, (tarihsiz).

230.0.0.0/57.8.1, 185-186, (15 Teşrinisani 1339/15 Kasım 1924).

230.0.0.0/61.25.2, 101-105, (19 Kanunuevvel 1926/19 Aral1k 1926).

230.0.0.0/61.25.2, 75-78, 81-93.

230.0.0.0/61.25.2, 93-94, (23 Kanunusani 1928/23 Ocak 1928).

230.0.0.0/61.25.2, 95, s. 2, 96-97, 99, (14 Kanunuevvel 1927/14 Aralik 1927).

30.18.01.01/10.29.12, 1, (15 Haziran 1340/15 Haziran 1924).

30.18.01.01/10.29.12, 2, (Haziran 1340/ Haziran 1924).

30.18.01.01/10.41.18, 1-2, (27 Ağustos 1340/27 Ağustos 1924).

30.18.01.01/14.47.15, 1, (29 Temmuz 1341/29 Temmuz 1925).

30.18.01.01/22.79.13, 4, (19 Kanunuevvel 1926/19 Aralı 1926).

30.18.01.01/22.79.13, 1, (21 Kanunuevvel 1926/21 Aralık 1926).

30.18.01.01/22.79.13, 1-3, (18 Kanunuevvel 1926/18 Aralık 1926). 
CUMHURIYYT'İN İLK YILLARINDA İSTANBUL-BÜKREŞ HAVAYOLU HATTI KURULMA ÇABALARI VE İMTIYAZI MESELESI

30.18.01.01/22.79.13, 2-3, (14 Kanunuevvel 1926/14 Aralık 1926).

30.18.01.02/19.22.9, (1 Nisan 1931).

30.18.01.02/19.22.9, (14 Mart 1931).

30.18.01.02/19.22.9, 4, 11 (14 Mart 1931).

30.18.01.02/19.22.9, 5, 10 (14 Mart 1931).

30.18.01.02/23.64.7, 1, 2, 7 (25 Ağustos 1931).

30.18.01.02/48.69.19, (11 Ekim 1934).

30.18.1.1/7.15.17, (17 Nisan 1923).

30.18.1.2/13.52.6, 1-3 (24 Temmuz 1930).

30.18.1.2/18.18.6, 1-33 (18 Mart 1931).

\section{Kitap, Makale ve Bildiriler}

ÇELIK, Ahmet, II. Meşrutiyet Döneminde Türk Hava Kuvvetleri, Selçuk Üniversitesi Sosyal Bilimler Enstitüsü, Yayımlanmamış Yüksek Lisans Tezi, Danışman: Yrd. Doç. Dr. İzzet Sak, Konya 2004.

DEMIR, Ahmet, Havacılık ve Uzay Endüstrisinin Yapısı, İşleyişi ve Türkiye'de Gelişme Olanakları Üzerinde Bir Araştırma, Ankara Üniversitesi Siyasal Bilgiler Fakültesi Yay., Ankara 1977, ss. 163-208.

Dünden Bugüne Türk Hava Yolları 1933-1983, (haz.) İlyas Albayrak, Cem Ofset, İstanbul 1985.

GEREDE, Ender, ORHAN, Gamze, "Türk Havayolu Taşımacılığındaki Ekonomik Düzenlemelerin Gelişim Süreci”, Havayolu Taşımacılığl ve Ekonomik Düzenlemeler Teori ve Türkiye Uygulaması, Sivil Havacılık Genel Müdürlüğü Yay., Ankara 2015, ss. 163-208.

GÖKNIL, Mazhar Nedim, Hava Hukuku, İstanbul Üniversitesi Hukuk Fakültesi Yay, İstanbul 1951.

GÖZLER, Kemal, Türk Anayasa Hukuku, Ekin Kitabevi Yay., Bursa 2000.

Havacılık Tarihi, Türk Tayyare Cemiyeti Yay., Ankara 1930.

HAYTOĞLU, Ercan, "Cumhuriyetin İlk Yıllarında Ticari Havayolu Taşımacılığında İmtiyazlı İlk Şirket: Aero Espresso Italiana (1924-1935)”, Hacettepe Üniversitesi Cumhuriyet Tarihi Araștırmaları Dergisi (CTAD), Y11 14, Say1 28, Güz 2018, ss. 75-109. 


\section{FEYZA KURNAZ ŞAHIN}

KANSU, Yavuz, ŞENSÖZ, Sermet, ÖZTUNA, Y1lmaz, En Eski Çağlardan I. Dünya Savaşına Kadar Havacılık Tarihinde Türkler I, Ankara 1971.

KARACAGIL, Kürşad, "Balkan Savaşlarında Osmanlı Devletinde Havacılık Faaliyetleri”, Türk Dünyası Araştırmaları, Sayı 200, Ekim 2012, ss. 73-90.

"Osmanlı Havacılık Teşkilatının Kuruluşuna Dair Nizamnameler”, Türk Kültürü Íncelemeleri Dergisi, Sayı 27, Güz 2012, ss. 43-76.

, Süreyya Ilmen'in Hayatı, Faaliyetleri ve Eserleri, Marmara Üniversitesi Türkiyat Araştırmaları Enstitüsü, Yayımlanmamış Doktora Tezi, Danışman: Prof. Dr. Süleyman Beyoğlu, İstanbul 2011.

KAYA, Ergün, Havaalanlarında Fiyatlandırma Açısından Muhasebe Bilgi Sistemi, Anadolu Üniversitesi Yay., Eskişehir 2000.

KİLECİ, Selçuk, "Hava Taşımacılığımızın Dünyadaki Yeri ve Kapasitenin Artırılması Hakkında Öneriler", IV. Uluslararası Havacılık Sempozyumu 5-6 Nisan 1993 Eskişehir, Anadolu Üniversitesi Yay., Eskiş̧ehir 1994, ss. 9-16.

KORALTÜRK, Murat, Erken Cumhuriyet Döneminde Ekonominin Türkleştirilmesi, İletişim Yay., İstanbul 2011.

LESPINOIS, Jérôme de, "Qu'est-ce que la Diplomatie Aérienne?", ASPJ Afrique \& Francophonie - 4e Trimestre, 2012, ss. 67-77.

MARKOVIC, Sacha, "Le Rôle de l'Etat Dans la Naissance de L'aviation Commerciale Française (1918-1933)", Revue Belge de Philologie et D'histoire, Histoire Medievale, Moderne et Contemporaine, Cilt 78, fask. 34, 2000, ss. 969-991.

MERAY, Seha, Lozan Barış Konferansı Tutanaklar Belgeler, İkinci Takım, Cilt II, 3. Bask1, Konferansta İmzalanan Senetler (30 Ocak ve 24 Temmuz 1923), Yapı Kredi Yayınları, İstanbul 2001.

Mustafa Kemal, Nutuk, Cilt II (1920-1927), MEB. Yay., İstanbul 1993. 
CUMHURIYYT'İN İLK YILLARINDA İSTANBUL-BÜKREŞ HAVAYOLU HATTI KURULMA ÇABALARI VE İMTIYAZI MESELESİ

SÜKAN, Bige, "İmparatorluktan Cumhuriyet'e Türkiye'de Yabancı Sermaye Anlayışı”, Ankara Üniversitesi Türk Inkılâp Tarihi Enstitüsü Atatürk Yolu Dergisi, Say1 54, Bahar 2014, ss. 195-222.

SÜRMELİ, Fevzi, SEÇİM, Hikmet, SÖZBİLİR, Halim, Sivil Havacılı Yönetimi, Anadolu Üniversitesi Yay., Eskişehir 1991.

Türk İstiklal Harbi Vnci Cilt, Deniz Cephesi ve Hava Harekatı, Genelkurmay Başkanlığı Yay., Ankara 1964.

TÜZÜN, Necat, Hava ve Kara Taşıma Hukuku, Ankara İktisadi ve Ticari İlimler Akademisi Yay., Ankara 1981.

YALÇINKAYA, Akansel, "Türk Havayolu Taşımacıllı̆g 1 Sektörünün Tarihsel Gelişimi ve Devlet Müdahaleleri (1933-2006)", Hacettepe Üniversitesi Cumhuriyet Tarihi Araştırmaları Dergisi (CTAD), Yı1 15, Sayı 29, Bahar 2019, s. 405-442. 


\section{FEYZA KURNAZ ŞAHIN}

\section{EKLER}

Ek-1 Franco-Romen Havaî Seyrüsefer Şirketi’nin Tesis Ettiği Havayolu Hattı

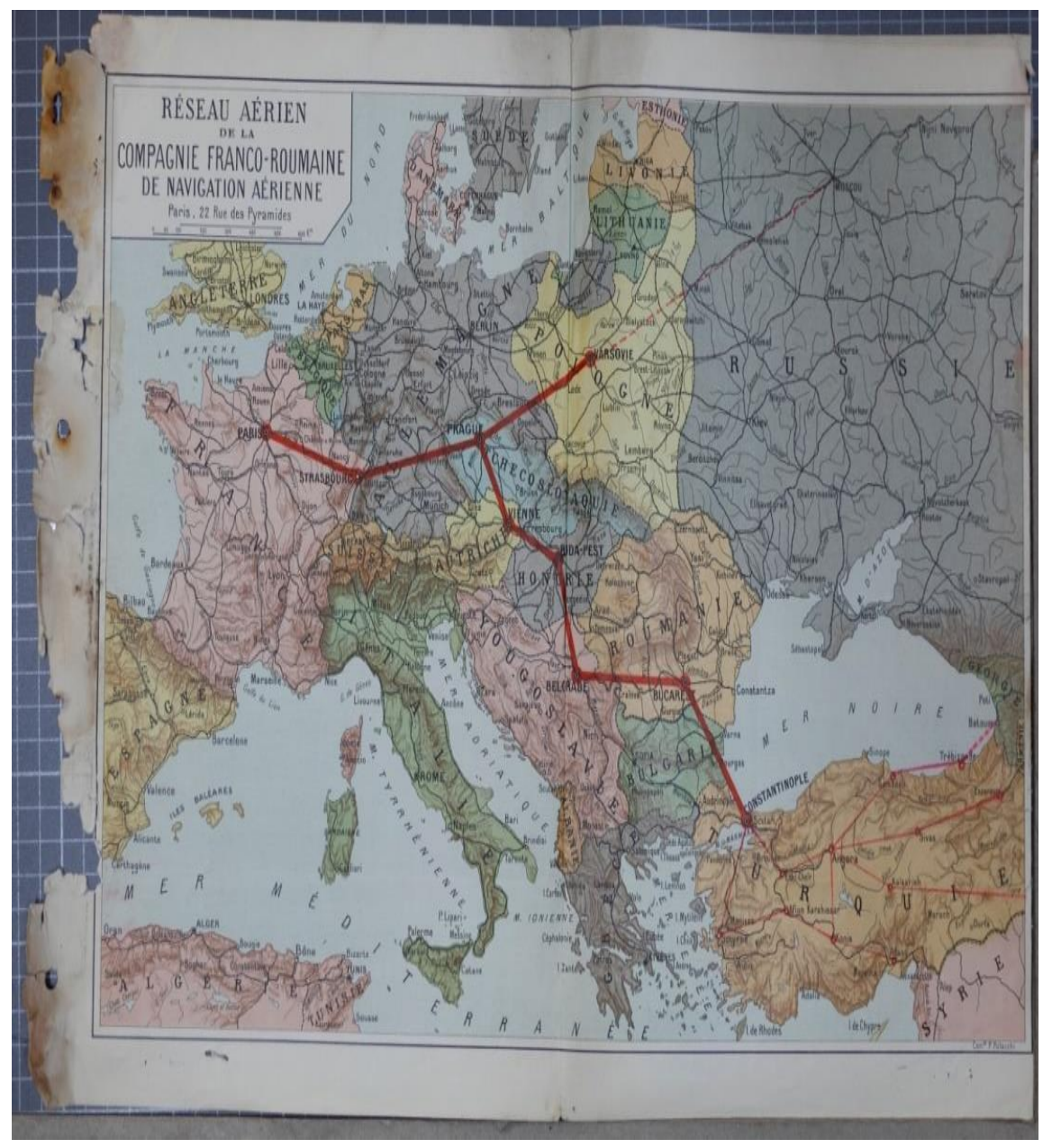

BCA, 230.0.0.0/57.8.1, 126, (tarihsiz). 


\section{CUMHURIYET'IN IILK YILLARINDA İSTANBUL-BÜKREŞ HAVAYOLU HATTI KURULMA ÇABALARI VE IMTIYYAZI MESELESI}

Ek-2 Franco-Romen Havaî Seyrüsefer Şirketi'nin Faaliyetlerini TBMM'ye Tanıtmak İçin Hazırladığı Dosyadan Bir Fotoğraf

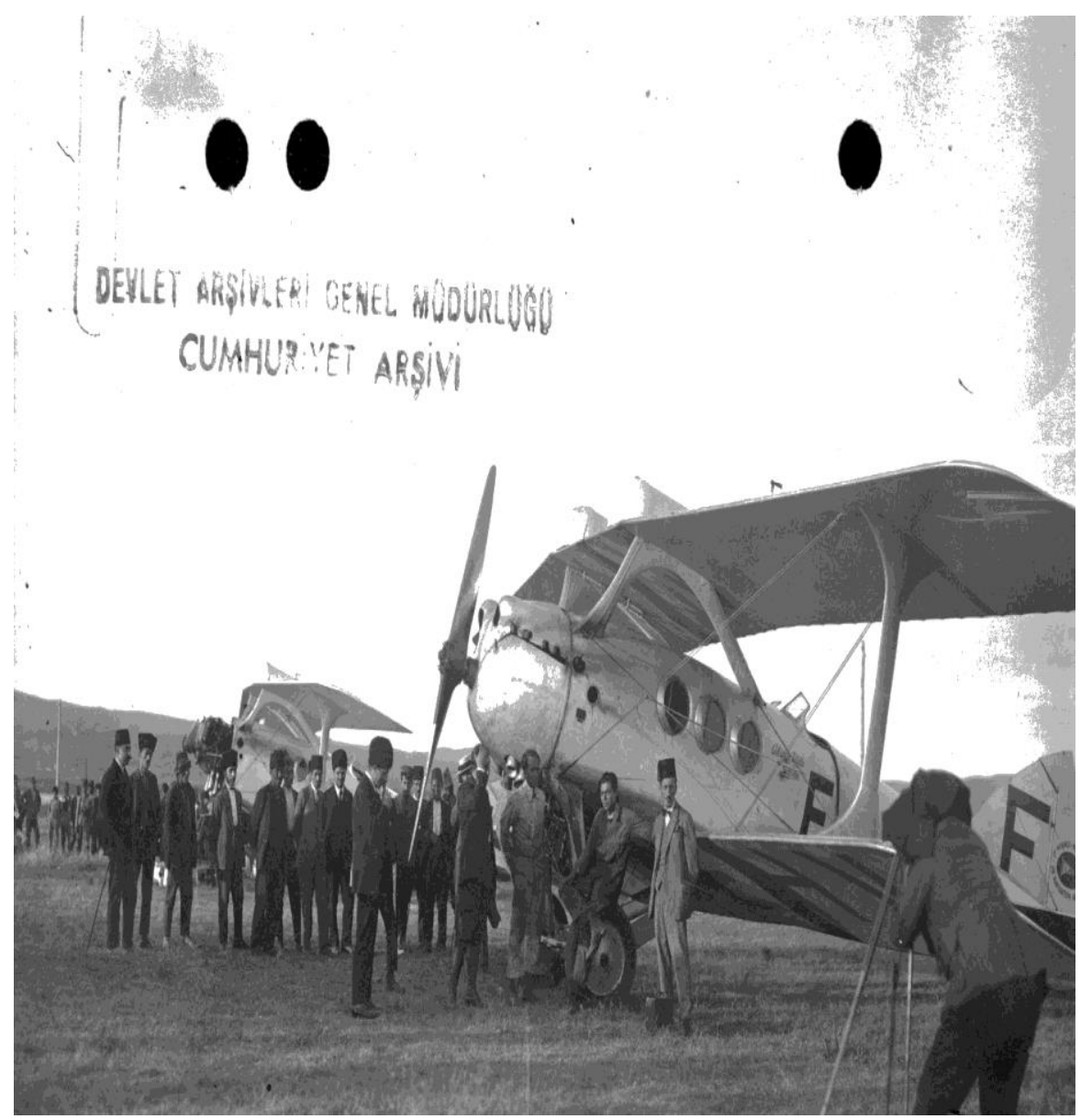

BCA, 230.0.0.0/59.15.1, 203 (22 Aralık 1923). 


\section{FEYZA KURNAZ ŞAHIN}

Ek-3 Beynelmilel Havaî Seyrüsefer Şirketi (CIDNA) İle Türkiye'nin 17 Ağustos 1925 Tarihinde İmzaladığı Mukavelenin İlk Sayfası

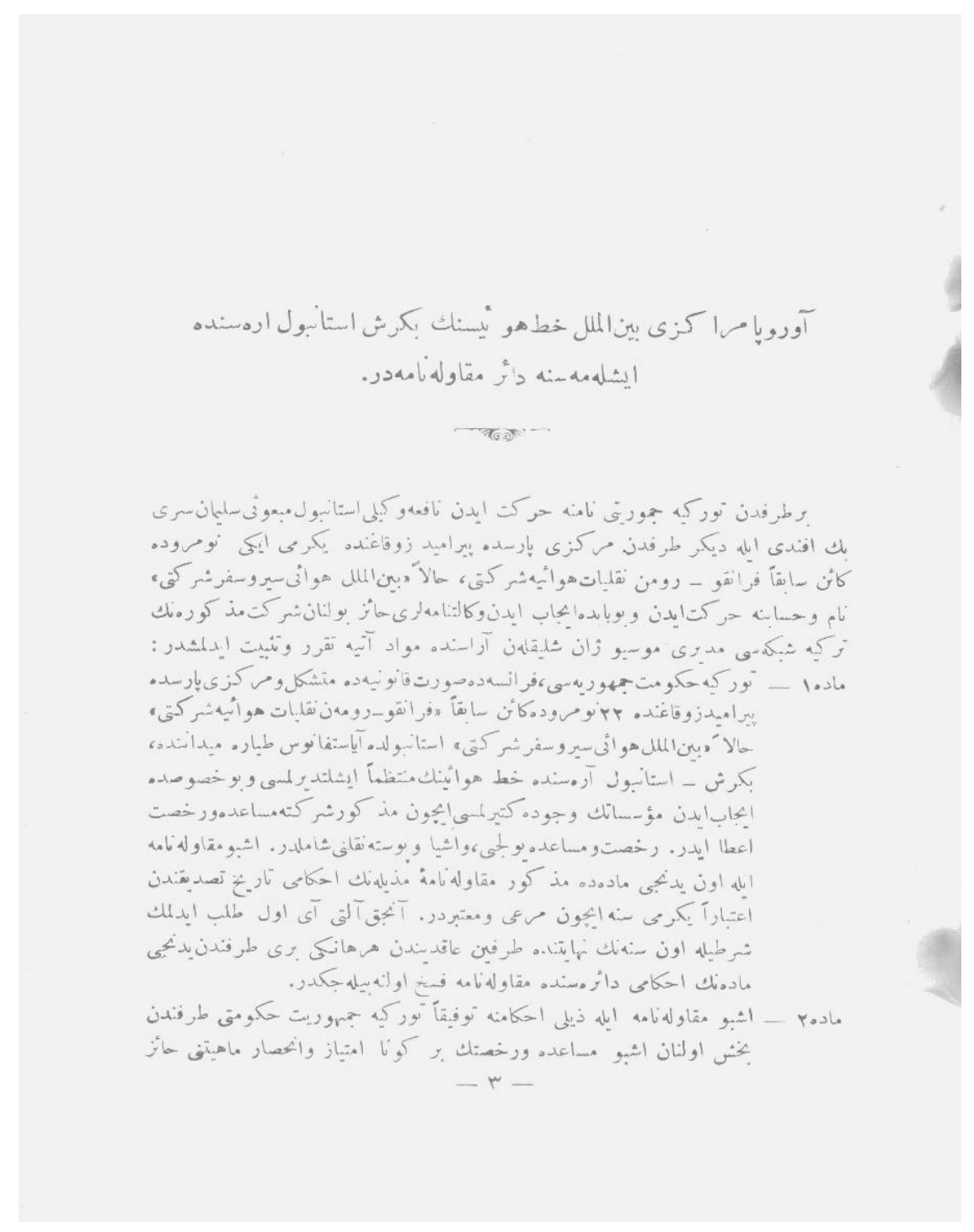

BCA, 230.0.0.0/57.6.1, (17 Ağustos 1341/17 Ağustos 1925). 
CUMHURIYET'İN İLK YILLARINDA İSTANBUL-BÜKREŞ HAVAYOLU HATTI KURULMA ÇABALARI VE İMTIYAZI MESELESİ

Ek-4 Beynelmilel Havaî Seyrüsefer Şirketi (CIDNA)'nin Yeşilköy'de Gerçekleştireceği İnşaat Projesi

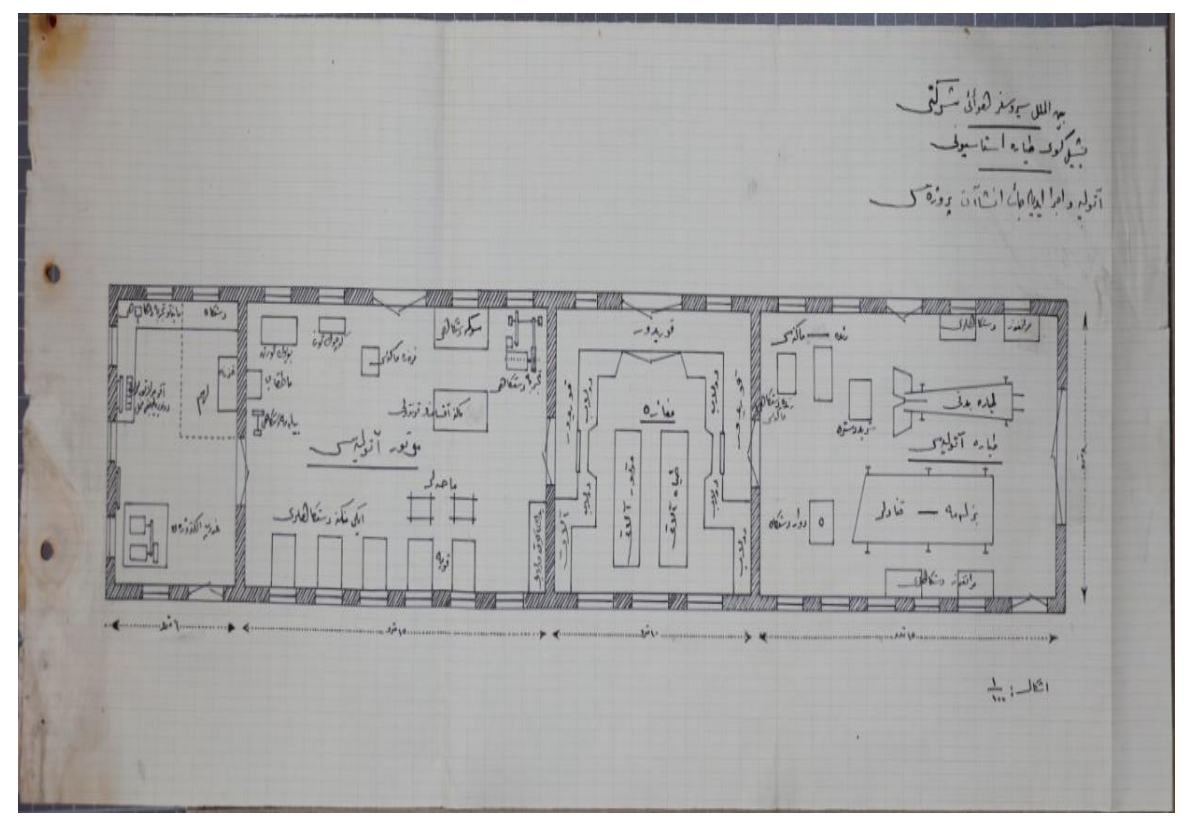

BCA, 230.0.0.0/57.8.1, 42, (30 Teşrinisani 1341/30 Kasım 1925). 